Pamiętnik Literacki 2017, 1, s. 23-48
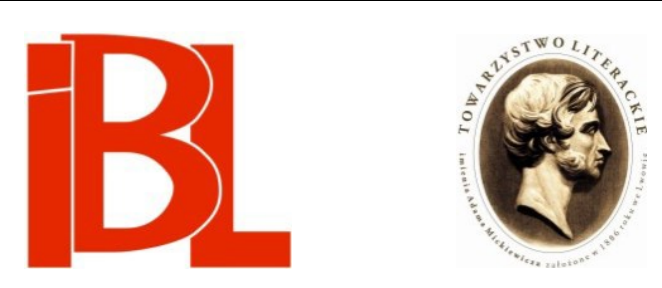

Między historią a biografią. Funkcjonowanie myśli Stanisława Brzozowskiego w latach

$$
\text { 1945-1948 }
$$

Paweł Rams 
PAWEŁ RAMS Instytut Badań Literackich PAN, Warszawa

\section{MIĘDZY HISTORIĄ A BIOGRAFLĄ FUNKCJONOWANIE MYŚLI STANISŁAWA BRZOZOWSKIEGO W LATACH 1945-1948}

Za daty graniczne badanego okresu przyjąłem lata 1945 i 1948. Ich wybór nie został podyktowany konkretnymi wydarzeniami historycznymi ${ }^{1}$, lecz ukazywaniem się interesujących mnie tekstów. W roku 1945, już po oficjalnym zakończeniu wojny, pojawiają się pierwsze wzmianki na temat autora Legendy Młodej Polski w czasopismach krajowych. Z kolei rok 1948 (a właściwie jego okolice) to okres, kiedy powoli, pod wpływem nacisków politycznych, milkną głosy wyrażające opinie i sądy odmienne od oficjalnie przyjętych. Dotyczy to także Stanisława Brzozowskiego. Jak w każdej próbie periodyzacji - jednym z podstawowych problemów jest arbitralność ustanawianych granic, którym nie poddają się wydarzenia społeczne, a tym bardziej kulturalne. $Z$ uwagi na poruszany temat siłą rzeczy zmuszony zostałem do analizy wybranych zjawisk wychodzących niejednokrotnie poza obrane przeze mnie ramy czasowe i terytorialne. Prace powstałe przed 1945 rokiem, jeszcze w okresie Dwudziestolecia międzywojennego czy okupacji, traktować będę jako pomocnicze, ułatwiające identyfikację opisywanych zjawisk. Zupełnie inaczej przedstawia się sprawa $\mathrm{z}$ artykułami wydawanymi za granica. Mają one niebagatelne znaczenie jako głosy w dyskusji nad dziedzictwem polskiej myśli socjalistycznej. Istotne jest również to, że dobiegają one z odmiennej rzeczywistości politycznej i społecznej, dzięki czemu rzucają światło na debatę dotyczącą dziedzictwa Brzozowskiego w Polsce Ludowej.

Zadanie, które przed soba postawiłem, to nie tylko zebranie i opisanie materiału. Chciałbym, w oparciu o analizę tekstową, biorąc pod uwagę kontekst spo-

1 W opracowaniach historycznych panują rozbieżności w obieraniu punktu rozpoczynającego nowy okres w historii Polski. Często przyjmowana jest data 21 VII 1944, kiedy to Krajowa Rada Narodowa wydaje dekret o utworzeniu Polskiego Komitetu Wyzwolenia Narodowego. Właśnie ona zostaje obrana przez A. L. S o w ę w książce Historia polityczna Polski 1944-1991 (Kraków 2011). Wydarzenie to zostaje podane jako jedno z pierwszych w pracy M. Fik Kultura polska po Jatcie. Kronika lat 1944-1981 (London 1989). J. E isler (Zarys dziejów politycznych Polski 1944-1989. Warszawa 1992) rozpoczyna narrację od dnia 20 VII 1944, a więc od momentu sforsowania Bugu pod Dorohuskiem przez wojska marszałka K. Rokossowskiego. K. Ke r s t en (Narodziny systemu władzy. Polska 1943-1948. Warszawa 1985) przesuwa tę datę do chwili bitwy o Stalingrad wygranej przez ZSRR, czyli do punktu, w którym zatrzymuje się zwycięski marsz wojsk hitlerowskich, inicjatywę zaś przejmuje Armia Czerwona. A. Pa czk ow ski (Pół wieku dziejów Polski. Wyd. 5, rozszerz. Warszawa 2007, s. 8) z kolei lata okupacji i okres powojenny opisuje razem. Swoją decyzję uzasadnia w sposób następujący: „Ponieważ istota i forma tej państwowości [tj. Polski Ludowej] wynikła przede wszystkim jako skutek biegu wydarzeń II wojny światowej, uznałem, iż objęcie ich wspólnym wykładem raczej ułatwi, niż skomplikuje całość wywodu". 
łeczny, polityczny i kulturalny, omówić i zinterpretować wielość i często zaskakującą wręcz zmienność interpretacji dorobku Brzozowskiego. Tym sposobem zobrazuję także, na zasadzie pars pro toto, interesujące mnie lata jako czas zmian, nadziei, lęków, prób radzenia sobie $z$ zastanym światem, wyrażony stosunkiem do polskiego filozofa, publicysty i pisarza przełomu XIX i XX wieku. Podobnie jak za życia także długo po swojej śmierci pisarz wzbudzał kontrowersje, rodził skrajne emocje: od bezgranicznego uwielbienia po potępienie. Wypowiedzi na temat Brzozowskiego w okresie istnienia Polski Ludowej stanowiły nie tylko próby zmierzenia się z dziedzictwem polskiej lewicy, próby usankcjonowania nowej rzeczywistości społecznej w rodzimej tradycji, ale również próbe pisania subiektywnej opowieści, narracji o procesie historycznym z perspektywy jednostkowej, a także próbe odnalezienia własnego miejsca w zmienionych warunkach. Jednym słowem, należało ten świat oswoić oraz znarratywizować i temu też służył Brzozowski².

Chciałbym, aby moja analiza dyskursu, jaki kształtował się wokół postaci Brzozowskiego tuż po wojnie, była połączeniem dwóch sposobów pisania: historii i o historii. Stanowiłaby, po pierwsze, ujęcie procesu dziejowego, po drugie - doświadczenia jednostkowego. Zadanie to może się wydawać karkołomne. Jak bowiem, omawiając teksty o charakterze światopoglądowym i filozoficznym, połączyć dwa diametralnie różne style mówienia o historii? W moim przekonaniu - obranie takiego, a nie innego materiału analitycznego pozwoli uzgodnić obydwie narracje. Gdyż, z jednej strony, artykuły będące przedmiotem mojego zainteresowania stanowią zapis autentycznych prób usensownienia świata przy zastosowaniu kategorii zaczerpniętych $z$ tradycji polskiego ruchu lewicowego. $Z$ drugiej - ukazuja konieczność poradzenia sobie z ideologicznymi i politycznymi naciskami. To rozdarcie doskonale widać w pracach o Brzozowskim. Lata 1945-1948 są szczególnie predestynowane do tego typu opisu ze względu na bogactwo i niejednorodność, czasami wręcz chaotyczność życia politycznego, społecznego i kulturalnego ${ }^{3}$. Nie zgadzam się w tym względzie ze słowami Janusza Sławińskiego:

Zauważmy: cała w istocie historia życia duchowego w Polsce powojennej jest tak czy inaczej zrelatywizowana do tego paroletniego okresu - stalinowsko-bierutowskiego. To wszystko, co go poprzedzało - poczynając od miesięcy letnich 1944 roku - narzuca się nam ze swoją dwoistością: z jednej strony, było to stopniowe - i w jakiejś mierze jeszcze skryte - krystalizowanie się polskiej wersji stalinizmu, z drugiej zaś trwanie swego rodzaju realności negatywnej, stan rzeczy, który musiał zostać przezwyciężony, by stalinizm mógł się dopełnić. Lata 1944-1948 nie mają sensu innego, jak tylko ten, którym wypełnia je okres następny4.

O narracji jako o elemencie budowania tożsamości i oswajania świata pisze A. Łebkowska (Narracja. W zb.: Kulturowa teoria literatury. Główne pojęcia i problemy. Red. M. P. M a r k ow s ki, R. Ny c z. Kraków 2006, szczególnie s. 191-199).

3 Różnorodność tę w sferze czasopiśmiennictwa omawia L. Szar u ga w pracy Czasopisma literackie (w zb.: Literatura polska 1918-1975. T. 3, cz. 1: 1945-1975. Red. nauk. A. B rod z k a, T. Bujnicki. Warszawa 1996, zwłaszcza s. 214-225).

4 J. Sław iński, Krytyka nowego typu. W: Teksty i teksty. Kraków 2000, s. 160. Prace wybrane. T. 3. Takie postawienie sprawy przez autora jest o tyle ciekawe, że kilka stronic dalej pisze on: „W istocie życie literackie lat 1944-1947, a zwłaszcza sposób funkcjonowania w nim opiniodawstwa krytycznoliterackiego, stanowiło pod licznymi względami kontynuację międzywojennego życia literackiego $z$ jego policentryzmem, wielogłosowością i ścieraniem się stanowisk. Mimo ostrych ograniczeń cenzuralnych, mimo utrudnień stwarzanych pewnym środowiskom i orientacjom przy 
Według mnie twierdzenie takie wydaje się nieuzasadnione w zderzeniu z licznymi faktami i analizami tekstowymi. Pogląd wyrażony przez Sławińskiego zakorzeniony jest w przekonaniu, że lata 1948-1955 wiążą się z - jedną $z$ największych w dziejach - tragedia polskiej kultury oraz że okres epokę tę poprzedzający był niczym innym niż preludium do upadku sztuki i literatury. O ile z pierwszym twierdzeniem bez trudu można się zgodzić, o tyle drugie budzi liczne wątpliwości. Opiera się ono bowiem na anachronizmie. Jednym $z$ zadań, jakie przed sobą stawiam, jest próba udowodnienia, że lata poprzedzajace „właściwy stalinizm” nie tylko stanowiły wstęp do niego, ale były czasem niejednoznacznym, obfitującym w wizje, nadzieje i marzenia, a przez to wyjątkowym i wyrazistym.

Coraz wyraźniej, kiedy podchodzi się do współczesnej myśli europejskiej, uświadamia się sobie konieczność, ale i możliwość - syntezy. Konieczność oddzielenia od siebie myśli przeszłej i współczesnej, splecionych ze sobą zagmatwanie i gęsto jak korzenie dwu drzew. Trzeba dla samodzielnych, pozornie niezależnych i z niczym nie związanych korzeni znaleźć ich wspólną konsekwencję, cel, któremu korzenie służą. Trzeba objać pień myśli współczesnej, który z korzeni wyrasta.

Zarówno bowiem zagadnienie „intuicji rzeczywistości”, jak zagadnienie związku świadomości kulturalnej z tymi procesami, gdzie się owa rzeczywistość tworzy i rozrasta, jak zagadnienie osadzenia człowieka w jakimś konkretnym środowisku, w jakichś określonych warunkach egzystencji - wszystko to były korzenie, może i rozchodzące się pozornie w różnych kierunkach, skrzyżowane ze sobą, lecz należące do tego samego wielkiego pnia myślowo-emocjonalnego. [T 239] ${ }^{5}$

Cytat ten, pochodzacy z tekstu Andrzeja Trzebińskiego opublikowanego w roku 1942 w czasopiśmie „Sztuka i Naród”, doskonale oddaje klimat, jaki towarzyszył intelektualistom podczas ostatnich lat wojny i zaraz po jej zakończeniu. Wobec wydarzeń, których byli oni świadkami, wobec kryzysu wyznawanych wartości zaistniała konieczność określenia siebie na nowo w rzeczywistości rodzącej się w ogniu walk. Jakie idee należało bezpowrotnie pogrzebać i potraktować jako stracone, jakie z kolei można było wydobyć $z$ ruin, przekształcić, by znów przysłużyły się budowaniu świata? Jakie wreszcie idee należało powołać do życia? Te pytania towarzyszyć mi będą podczas analizy zebranego materiału. Już w ostatnich latach wojny, gdy wojska niemieckie znalazły się w defensywie, wielu przewidywało rychły koniec walk, a jednocześnie koniec znanego świata ${ }^{6}$. Trzeba było przygotować się

równoczesnym uprzywilejowaniu ekonomicznym czy wydawniczym innych toczyła się tu jednak autentyczna gra idei, upodobań i ocen" (ibidem, s. 165). O niejednorodności tego okresu pisze również S. Żółkiews ki w przedmowie do zbioru swoich tekstów publicystycznych zgromadzonych w tomie Cetno i licho. Szkice 1938-1980 (Warszawa 1983).

5 Skrótem T odsyłam do: A. Trz eb iń s ki, Korzenie i kwiaty myśli wspótczesnej. W zb.: Jest Bóg, żyje prawda. Inna twarz Stanisława Brzozowskiego. Wybór, wstęp, red. M. U r b a n ow s ki. Kraków 2012. Ponadto w artykule stosuję takie skróty: A = S. Ad a m c ze w s ki, Patronat Brzozowskiego. „Nauka i Sztuka” 1946, nr 4. - H = G. Herling-Grudziń ski, Nota o Brzozowskim. W zb.: Jest Bóg, żyje prawda. - K = K. Koźn i e w s ki, „Płomienie” Brzozowskiego. „Twórczość” 1948, z. 4. - KS = J. Kulc zy c ka - S a l o n i, O „Płomieniach” Stanisława Brzozowskiego. Nowa recenzja bardzo starej powieści. Rec.: S. Brzozow sk i, Płomienie. Wyd. 3. Kraków 1946-1947. „Kuźnica” 1948, nr 32. - L = Cz. La t a w i e c, Ideologia Brzozowskiego a chwila obecna. „Zdroje Sztuki, Literatury i Nauki” 1945, nr 1. - S = M. S tę p i eń, Spór o spuściznę po Stanisławie Brzozowskim w latach 1918-1939. Kraków 1976. $-Z$ = S. Za h or s k a, Myśli o Brzozowskim. W zb.: Jest Bóg, żyje prawda. Liczby po skrótach oznaczają numery stronic.

6 Napięcie oraz nieprzewidywalność wydarzeń, zmieniające się losy wojny nawet w okresie ostatnich 
na nowe. Obok potyczek militarnych, rozgrywających się na polach bitewnych, w setkach głów dokonywała się wojna intelektualna o nowy obraz świata, człowieka, ale także o własne miejsce w nowej rzeczywistości. Taka postawa mocno zaznacza się w tekście Trzebińskiego. Podnosi on bowiem jeden z najważniejszych wątków w twórczości Brzozowskiego, a mianowicie konieczność kształtowania własnej egzystencji nie w oderwaniu od rzeczywistości, ale w nierozłącznym $z$ nią sprzężeniu. Autor cytowanego fragmentu wykorzystuje tę okazję, by przewartościować zastane imponderabilia i niezachwiane prawdy wiary. Szansę upatruje w nowocześnie pojmowanym nacjonalizmie, zagrożenia zaś w socjalizmie i komunizmie. Tę walkę między dwiema koncepcjami świata oraz uwięzionej w nim jednostki doskonale oddają następujące słowa:

Rewolucyjność myśli Nacjonalizmu jest czymś więcej niż przywiązaniem do czerwonego koloru, manifestacyjnych pochodów i różnych teatralnych emblematów pracy, jak sierp i młot. Ma pogardę dla tradycyjności, dla schematów egalitarystycznych i niszczycielskich rewolucji Kosmopolityzmu. Jest zakrojoną na skalę rewolucji, która zmieniając - tworzy. [T 242-243]

Nacjonalizm, rozumiany przez Trzebińskiego jako idea rewolucyjna, w przeciwieństwie do „czerwonej rewolucji”, która poprzez swój kosmopolityzm niszczy struktury tradycyjne, to rewolucja budujacca. Obce są autorowi idee ponadnarodowe, bliskie zaś te odnoszące się do lokalnych warunków. Na patronów tak rozumianej rewolucji powołani zostają Maurice Barrès oraz Stanisław Brzozowski ${ }^{7}$. W obliczu destrukcji wojennej - idąc za myśla swych przewodników intelektualnych - autor postuluje stworzenie nowego człowieka ${ }^{8}$. Rewolucja wymaga nie tylko przebudowy świata zewnętrznego, ale także świata wewnętrznego jednostki. Właśnie ta myśl mocno wiąże Trzebińskiego ze spuścizną po Brzozowskim. Patrzenie na osobę i otaczająca ją rzeczywistość jako na symbiozę tych dwóch elementów ma niebagatelne znaczenie. Zdaniem Trzebińskiego, wszelkie idee (w tym też Absolut) są „sokiem ziemi, w której tkwimy korzeniami, są bezwzględną i niepowtarzalną ceną naszego miejsca na ziemi” (T 245). Korzenie i kwiaty myśli współczesnej stanowią próbę stworzenia nowego systemu, systemu rewolucyjnego, który w obliczu wojennego spustoszenia daje nadzieję na odrodzenie się świata i człowieka.

W przypadku Trzebińskiego kwestia patronatu Brzozowskiego wydaje się jasna. Krytyk wybiera go ze względu na podobieństwo pewnych idei do własnego rozumienia nacjonalizmu (inna sprawa, jak dalece owe podobieństwa są głębokie, w jakim zaś stopniu wynikają ze zwykłych skojarzeń bądź nadinterpretacji). W dużo gorszej sytuacji znajdowały się osoby, które przed wojną działały w ruchu lewicowym.

miesięcy jej trwania - tak wśród polityków, żołnierzy, jak i cywilów stara się ukazać B. Sh e p ha r d w książce Powrót (Przeł. J. D z i e r z g o w s ki. Warszawa 2016).

7 Zob. T 243: „Aż zdziwienie ogarnia niekiedy, gdy zestawia się ze sobą kwiaty - bo nie owoce jeszcze - myśli Stanisława Brzozowskiego z rozkwitającą myślą Nacjonalizmu. Nacjonalizmu polskiego dodajmy. Uderza ta wspaniała zbieżność obu toków myślowych, powierzchownie tak odmiennych". Zob. T 245:

„Źródłem ma być tu rewolucyjne przebudowanie człowieka. Nastawienie człowieka tak, aby zaczął [on] realizować cele. U źródeł myśli Nacjonalizmu tkwi twórcza i celowa (a nie naturalnie i bezcelowo wybuchła!) rewolucja.

Rewolucja charakteru". 
Musiały one zmierzyć się nie tylko z dziedzictwem autora Legendy Młodej Polski, ale także $z$ wpływem, jaki wywarł on na lewicę w Dwudziestoleciu międzywojennym. Naturalnie również w kręgach nacjonalistycznych i katolickich w tamtym okresie Brzozowski stanowił przedmiot zainteresowania. Tym samym Trzebiński mógł sięgnąć do znanej sobie tradycji ${ }^{9}$.

Bitwa o Brzozowskiego w kręgach lewicy toczyła się na dużo szerszym polu, stawka bowiem, o która grano, była bez porównania większa. Chodziło mianowicie o zdecydowanie, czy autora Płomieni traktować można jako patrona polskiej lewicy rewolucyjnej. Zagadnienie to okazało się niebagatelne. Brzozowskiego już za jego życia uznawano za jednego z czołowych polskich interpretatorów marksizmu, a opinia ta przetrwała w umysłach wielu działaczy, którzy przeżyli pierwszą wojnę światową i w wolnej Polsce tworzyli zręby organizacji lewicowych. Filozof miał więc liczne grono obrońców, wśród których wymienić trzeba Juliana Bruna-Bronowicza, Stanisława Baczyńskiego, Oskara Langego, Karola Kuryluka czy Maksymiliana Boruchowicza (po wojnie używał on nazwiska Borwicz). Nie da się jednak zlekceważyć rangi przeciwników Brzozowskiego, a więc Jana Nepomucena Millera, Andrzeja Stawara, Jerzego Borejszy, Henryka Lukreca, Mieczysława Haresza, Ludwika Frydego czy Ignacego Fika. Pierwsi dostrzegali w autorze Idei wielkiego krytyka literackiego i teatralnego ${ }^{10}$, erudytę, krytyka Polski zdziecinniałej, etyka wyznaczajacego nowe tory polskiej myśli, a nade wszystko reinterpretatora filozofii marksistowskiej. Drudzy z kolei udowadniali, że Brzozowski nie jest nikim więcej niż ideologiem polskiego mieszczaństwa, bezrefleksyjnym chwalca pracy, krytykiem o nieustabilizowanym poglądzie na rzeczywistość, powierzchownym marksistą, któremu bliżej do Georges'a Eugène’a Sorela i faszyzmu niż do Marksa, a wreszcie osobą, której erudycja była najzwyczajniej niechlujstwem myślowym ${ }^{11}$. Jeden $z$ podstawowych zarzutów stawianych filozofowi $z$ pozycji komunistycznych to zupełne pominięcie teorii walki klasowej. Pamięć o tych dyskusjach bądź bezpośredni w nich udział stały się dla wielu reprezentantów powojennej inteligencji polskiej punktem odniesienia. Po roku 1945 w rodzącym się państwie, dążącym do spełnienia postulatów komunistycznych, należało na nowo przemyśleć dziedzictwo Brzozowskiego.

Cechą wspólną większości $z$ tekstów powstających w owym okresie jest stylizacja na wewnętrzny dialog z dotychczasowo przyjmowanymi przez danego autora założeniami. Zarazem wyobrażonym adresatem tych rozważań okazuje się nie jednostka, ale całe międzywojenne pokolenie o proweniencji lewicowej. Osoba pisząca przyjmuje funkcję sumienia narodu i z tej pozycji, wobec spustoszeń wojennych, próbuje na nowo pytać o sens, a przede wszystkim użyteczność dorobku Brzozowskiego w kształtowaniu postaw wobec ojczyzny, mającej stać się spełnieniem młodzieńczych marzeń. Jednym z koronnych przykładów jest Stanisław Adamczew-

Stępień (S 79-88) dzieli dyskusję nad dziedzictwem Brzozowskiego w kręgach katolickich na dwa wyraźne nurty: $z$ jednej strony, była to prosta - by nie rzec: prostacka - publicystyka spod znaku „Przeglądu Katolickiego”; z drugiej, próby głębszej, filozoficznej analizy jego dorobku podejmowane przez takie osobistości, jak R. Blüth czy s. Teresa Landy. Zob. Cz. La t a w i e c, Żeromski a Brzozowski. „Nowe Wici” 1926, nr 1.

10 Zob. M. Pru s s a k, Krytyka teatralna Stanisława Brzozowskiego. Wrocław 1987.

11 O recepcji Brzozowskiego w środowiskach lewicowych pisze St ę p i eń w swojej książce (S 17-35, 173-184). 
ski, znany i ceniony, acz dzisiaj już zapomniany, historyk literatury. Jeszcze przed wojną zaliczał się on do autorów prac na temat Brzozowskiego ${ }^{12}$. Wśród najpopularniejszych rozpraw znajdowała się rekonstrukcja pojęcia romantyzmu publikowana na łamach „Przeglądu Współczesnego”. Swoje rozważania o tym kończy Adamczewski w następujący sposób:

Romantyzm taki, jak go pojmuje i określa Brzozowski, nie przebrzmiał wraz z którymś z przeminionych okresów dziejowych, ale - w tej czy owej postaci trwa, króluje, żyje i działa pod różnymi maskami w dzisiejszym świecie umysłowej kultury - stąd poglądy Brzozowskiego na romantyzm nie zatraciły po dziś dzień aktualnego swego znaczenia. Powiem więcej: myślę, że teraz dopiero, w tej nieustannej wichurze dziejów, wśród której żyjemy od szeregu lat, staliśmy się lepiej przygotowani do pełnego rozumienia pism Brzozowskiego, że - gdy dzień nad nami zajaśniał i ukazał się oczom naszym świat nagi, bez upiornych mgieł - zaczynamy właściwiej niż dotąd pojmować, co wieściły owe dziwne i gorączkowe „głosy wśród nocy”. [cyt. S 61]

Ten nie w pełni aprobatywny, ale z pewnością przychylny ton drastycznie zmienia się prawie dwie dekady później, gdy Adamczewski w „Nauce i Sztuce” z roku 1946 zamieszcza artykuł Patronat Brzozowskiego?, rozpoczynając go w specyficzny sposób:

Oczywiście, chodzi tu o Stanisława Brzozowskiego, autora Legendy Młodej Polski, Idei, Głosów wśród nocy. Pojęcie patronatu wyjaśni się w zakończeniu, a znak zapytania, postawiony w tytule, jest odbiciem charakteru dyskusyjnego i dyskursywnego zarazem wywodów niniejszych, które zrazu pomyślane były jako odczyt, jako mówiony wyraz tych wątpliwości i niepokojów, jakie oblegają przy myśli o Brzozowskim. W samej więc intonacji, w toku retorycznym wywodu zachował się ślad tego dominującego niepokoju. I ślad tego, jak trudno dziś było przedmiot ten znów ruszyć z miejsca, dźwignąć z długotrwałego stanu milkliwej czy kłopotliwej inercji. Bo przedmiot jest istotnie $-\mathrm{z}$ tych cięższych. Różne są tego powody. A naprzód ten, że przedmiot ma naturę poniekąd - spowiedniczą. [A 31]

Równie trafnie jak spowiedzią można by nazwać ów tekst refleksją zbiorową. Adamczewski zabiera głos w imieniu całego pokolenia. Pisze o sobie jako o brzozowszczyku, ale nie w sensie wyznawcy, lecz osoby zaznajomionej gruntownie z dziełami młodopolskiego filozofa. Tekst ten jest spowiedzią dziecięcia pierwszej połowy XX wieku. Jego emocjonalny charakter pokazuje żywy związek autora $\mathrm{Z}$ omawiana problematyką. Dotyka go ona bezpośrednio, gdyż stanowi fundament jego tożsamości intelektualnej. Naczelne zadanie artykułu to próba określenia siebie na nowo w nowej rzeczywistości. Podmiot tekstu nie potrafi zdystansować się wobec tradycji, która była jego udziałem. Chociaż wielokrotnie widać próby oddalenia się od zajmującej go tematyki, to spojrzenie na sprawę chłodnym okiem staje się niemożliwe. Powodem jest fundamentalna wiara w związek między życiem wewnętrznym a otaczającą rzeczywistością, w kształtowanie własnej podmiotowości w starciu z siłami przyrody. To przekonanie nierozerwalnie łączy Adamczewskiego z Brzozowskim. Nawet kiedy twórca artykułu stawia zarzut współpracy autora Płomieni z rosyjską Ochraną, co nigdy nie zostało jednoznacznie rozstrzygnięte, to pyta, czy osoba taka, na której ciąży chociażby cień podejrzenia, może

12 Zob. m.in. S. Ad a m c ze w s ki: Teatr idei Brzozowskiego. „Kultura” 1932, nr 4; Taine i Brzozowski. „Sprawozdania z Posiedzeń Towarzystwa Naukowego Warszawskiego. Wydział I Językoznawstwa i Historii Literatury" 1938, z. 7/9. 
być brana za przykład ${ }^{13}$. Zarzut ten, wynikajacy bezpośrednio $z$ nierozerwalnej jedności czynów, myśli, pism i osoby, stanowi pytanie skierowane do samego siebie: pytanie o to, w jaki sposób polska lewica, w tym Adamczewski, piszacy o Brzozowskim przychylnie przed 1939 rokiem, ma postępować w obliczu doświadczeń niedawno zakończonej wojny, rzucającej nowe światło na niektóre idee potencjalnego patrona. Wśród owych idei Adamczewski wymienia biologizm, afirmację siły oraz narodu rozumianego w kategoriach naturalistycznych. Przyznaje też, że dużo łatwiej jest tym, którzy potrafili w okresie międzywojennym jednoznacznie negatywnie ocenić dorobek Brzozowskiego (A 36). Jak w takim kontekście należy postrzegać samego siebie, ulegającego pustym frazesom uznawanym kiedyś za prawdy wiary? Drugą część swoich rozważań kończy Adamczewski rozpaczliwym wykrzyknieniem: „Nie! to nie jest mistrz ani wzór, ani przewodnik jako myśliciel” (A 37). Próba odegnania patronatu Brzozowskiego nie przychodzi jednak łatwo. Okazuje się bowiem, że powinowactwa sięgają głęboko. Tym razem autor artykułu stara się rozprawić z mitem wybitnego krytyka literackiego. Ale i tu sytuacja nie jest prosta, gdyż styl Brzozowskiego, pomimo upływu lat, nadal nie stracił swego powabu. Jak przyznaje Adamczewski:

Za to, gdy da się [Stanisław Brzozowski] ponieść impetowi pisarskiemu, powstają karty pełne zastanawiających sformułowań i fascynujących metafor, karty, których ładunek emocjonalny nie stęchł, nie zwietrzał do dziś dnia. Wtedy uwodzi, urzeka, wytwarza jakąś nieodpartą narkozę, jakiś czar czy czad odurzający, któremu (przy pewnym typie czytelniczym) trudno się oprzeć. Nawet jego długie jakby zadyszane okresy, $\mathrm{z}$ natłokiem członów w przeładowanym myślą poprzedniku, z nagłym krótkim zamknięciem następnika - nawet one mają w sobie urok obcowania z żywym procesem myśli, narastającej i wyzwalającej się w toku pisania. Myśli człowieka, który ma świadomość związku wszystkiego ze wszystkim, i to związku równoczesnego, aby przeto myśli swej nie sfałszować, wszystkie te związki, koneksje, powinowactwa i skojarzenia zachowuje i utrwala w natłoczeniu pobocznych członów składniowych. Wszystkie manowce, rozwidlenia i zakamarki każdego ogniwa myśli stara się naraz, jednocześnie, $\mathrm{w}$ tym samym zdaniu zamknać. Uważa bowiem, że gdyby je rozbił na poszczególne zdania, powstałby niedokładny obraz jego myśli: obraz ukazujący związek jej elementów następczy, a nie równoczesny, co byłoby nie tylko niedokładnym odtworzeniem samego procesu myślowego, lecz - co gorsza - w umyśle czytelnika powstałaby konstelacja myślowa, także logicznie odmienna od autorskiej. [A 41]

Adamczewski nie potrafi wyzwolić się spod przemożnego wpływu stylu Brzozowskiego również dlatego, że styl ów jest częścią jego własnego warsztatu twórczego. Nawet jeżeli nie zrealizowanego, to pożądanego.

Ostatnia część omawianego artykułu stanowi próbę potraktowania Brzozowskiego jako zjawiska psychologicznego. W moim mniemaniu to właśnie najważniejsza część całego tekstu. Najpierw Adamczewski wylicza zadania, jakie stoja przed potencjalnym monografista filozofa. W grę wchodziłyby w tym wypadku nie tylko znajomość jego dzieł, prac i nurtów filozoficznych, do których Brzozowski się odwołuje, oraz wiedza historyczna czy wreszcie kontekst. Przede wszystkim poten-

13 W roku 1959 to samo pytanie zada A. St a w a r na łamach „Polityki” w numerze 12, w artykule Etyka $i$ ideologia. Jego odpowiedź będzie niejednoznaczna. Wzdryga się on bowiem przed postawieniem znaku równości między postulatami etycznymi Brzozowskiego a jego życiem, które wedle wielu (w tym Żeromskiego) musiało być bez skazy, by można było nazywać go sumieniem narodu. Stawar, odwołując się do biografii wybitnych osobistości, pokazuje, że stosunek ten wcale nie jest taki jednoznaczny. 
cjalny monografista musiałby być wytrawnym „duszoznawcą". Autor artykułu twierdzi, że jest to umiejętność niezbędna, gdyż każdy problem poruszony przez Brzozowskiego miał związek $z$ nim samym, był próba poradzenia sobie $z$ jakimś własnym niedomaganiem (A 43). W taki oto sposób Adamczewski postrzega swoją twórczość, czego najlepsze świadectwo stanowi analizowany tekst. Można twierdzić, że postulat zrozumienia siebie $\mathrm{w}$ akcie pisania dotyczy również formacji kulturowych. Tak bowiem jak Brzozowskiego nie da się odciąć od jego dzieł, od kontekstu, w którym kształtował samego siebie i z którego wyrastały jego myśli, tak tożsamości polskiej lewicy nie można budować w oderwaniu od tradycji, katastrofy wojny i prób odbudowania świata $\mathrm{w}$ zgodzie $\mathrm{z}$ własnymi ideami. Pytanie podstawowe przewijające się w artykule Adamczewskiego brzmi: w jakim stopniu wyznawane idee nadają się na budulec nowej Polski?

W przeciwieństwie do wielu późniejszych napisanych przez siebie tekstów Adamczewski w omawianym artykule nie szafuje nadmiernie ocenami, powstrzymuje się od ostatecznych rozstrzygnięć, nie potępia, a opinię pozostawia czytelnikowi. Efekt taki jest konsekwencją specyficznej retoryzacji: całość dowodzenia rozgrywa się na oczach czytelnika. Autor, przy udziale odbiorcy, prowadzi rozrachunek. W ten sposób ukazuje pozorny brak założonych celów, a tekst wydaje się ciagiem myśli kształtowanych "na żywo”, w obecności czytelnika. Jednocześnie staje się on uczestnikiem spowiedzi, nie tylko biernym widzem czy słuchaczem. Artykuł ma bowiem również charakter apelatywny. Wymusza na odbiorcy wykonanie takiej samej pracy, a więc rozliczenia się $z$ dziedzictwem brzozowszczyzny. Tak oto Adamczewski buduje pewną wspólnotę doświadczenia, czasami wręcz ją narzuca i nakazuje przemyślenie wizji nowej Polski oraz tematów związanych z tradycją, własną tożsamością - od początku.

Asumpt do rozliczenia się z przeszłością intelektualną dało pierwsze powojenne wznowienie najpopularniejszej powieści Brzozowskiego w wydawnictwie „Czytelnik" w 1946 roku. Płomienie, bo, oczywiście, o nich tu mowa, odegrały ogromna rolę $\mathrm{w}$ kształtowaniu lewicowych postaw polskiej inteligencji. Taki obraz książki wyłania się z recenzji Kazimierza Koźniewskiego opublikowanej w „Twórczości” w 1948 roku. Swoje wrażenia z lektury tekstów Brzozowskiego autor charakteryzuje w następujący sposób:

Publicystyka Brzozowskiego była może najbardziej drastycznym okazem „młodo-polskiej” szkoły pisarskiej, $z$ jej niewątpliwymi zaletami, ale równocześnie koszmarnymi wadami i pozami, jej namiętnościami - tak bardzo dalekimi od młodego człowieka wychowanego w międzywojennym Dwudziestoleciu [...]. Wojna i związane $\mathrm{z}$ nią perturbacje intelektualne bodajże pogłębiły jeszcze niechęć do Brzozowskiego, do jego rozwichrzonej metody pisarskiej i do obsesyjnego poszukiwania jakichś transcendentalnych, a mało konkretnych wartości. [K 109]

Tak jak u Adamczewskiego, mamy tutaj do czynienia z dwojaką postawą wobec myśli ideowej Brzozowskiego. $Z$ jednej strony, autor przytoczonego fragmentu nie może zaprzeczyć sile jej oddziaływania, nie może jej odmówić mocy perswazji, $z$ drugiej jednak - pod wpływem wydarzeń historycznych - pojawia się wątpliwość co do jej rewolucyjności, a na plan pierwszy wysuwają się te elementy, które wskazywałyby na tendencje faszystowskie w myśleniu Brzozowskiego. Konstatację tę dałoby się zakończyć w tym punkcie, gdyby nie fakt, że Koźniewski, podobnie jak Adamczewski, próbuje rozliczyć się $\mathrm{z}$ własną przeszłością. Tekst napisany został 
w 1948 roku, a więc w czasie stabilizacji dominującej roli PPR w życiu politycznym Polski. Pozwala to w zupełnie innym świetle odczytać ów artykuł. Choć jego ton nie jest tak dojmujący, jak w przypadku tekstu Patronat Brzozowskiego?, to ze względu na specyficzna sytuację dziejową pozwala odmiennie spojrzeć na postawę przyjmowana przez polską inteligencję lewicową wobec utopii ziszczającej się na ich oczach $^{14}$. Już pierwsze akapity recenzji Płomieni pomagają rozpoznać stawkę, o która toczy się gra. Autor pisze wprost, że powieść wywarła na nim wielkie wra$\dot{z ̇ e n i e}^{15}$. Tak wielkie, iż również 14 lat później (jak twierdzi, pierwszy raz miał z nia styczność w 1934 roku) jej reedycję uważa za istotne wydarzenie kulturalne ${ }^{16}$. Więcej nawet. Stwierdza, że powieść ta jest tak samo czytelna jak przed wojną, a temat konspiracyjnej walki ze znienawidzona władza nabiera zupełnie nowego sensu po tym, co się stało w czasie drugiej wojny światowej ${ }^{17}$. Na słowach tych odciska piętno działalność konspiracyjna Koźniewskiego ${ }^{18}$. Właśnie przez ten pryzmat patrzy on na Płomienie i to dlatego powieść wydaje mu się tak aktualna.

Pomimo możliwości przejrzenia się w wydarzeniach i postaciach Koźniewski nie potrafi wyzbyć się licznych wątpliwości. Próbuje odpowiedzieć na pytanie, czy wahania te wynikały z prawdziwej potrzeby przemyślenia siebie na nowo, czy raczej wymuszone zostały przez nowa sytuację polityczną. Nie zapominajmy, że był to trudny czas dla ludzi kultury, nauki i sztuki. Nie chodzi mi tu wyłącznie o stronę materialną, choć i ona pozostawiała wiele do życzenia, ale o konieczność sprostania rozdarciu między stawianymi przez władzę wymaganiami a własną historią i imperatywem bycia wiernym sobie. Trzeba więc było znaleźć ścieżkę łącząca „"ja" przeszłe” z „"ja" teraźniejszym”, szczególnie wtedy, gdy miało się do czynienia z dramatycznymi wydarzeniami historycznymi zrywającymi wątki ludzkiego życia i plączącymi je. Przywołajmy dłuższy cytat z recenzji Koźniewskiego:

Inną przyczyną budzącą zainteresowanie dzisiejszego czytelnika jest sprawa rosyjska w Płomieniach. Jest to rzecz zresztą szczególnie skomplikowana. $\mathrm{W}$ istocie całe młode pokolenie polskie wychowane w okresie po uzyskaniu Niepodległości nie miało i nie ma wielkiego pojęcia o Rosji i o Rosjanach. Rosja - była dla nas jakimś rozdziałem wrogim i już zamkniętym. Ojcowie wspominali ją raczej niechętnie, a my nie odczuwaliśmy wielkiej potrzeby interesowania się dawną Rosją choćby dlatego, że Rosja wspó1czesna nam, Rosja sowiecka, była czymś znacznie ciekawszym i ważniejszym. Trzeba było dopiero kataklizmu wojennego, radzieckiej „wojny ojczyźnianej”, czołgów idących na Berlin pod hasłem Suworowa i Kutuzowa, byśmy mogli pojąć, że Rosja radziecka nie zerwała wszystkich więzów łączących ją z Rosją dawną, nie carską, ale narodową, dziesięciowieczną.

O wahaniach polskiej inteligencji wobec rządów PPR, potem zaś PZPR pisze m.in. B. Fijałkows k a w książce Polityka i twórcy (1948-1959) (Warszawa 1985).

15 Zob. K 109: „Pochłanialiśmy [tj. Koźniewski i jego rówieśnicy w okresie międzywojennym] je [tj. powieści Brzozowskiegol jednym tchem, tak gorąco - że fabuła powieści rychło $\mathrm{z}$ nas wyparowała, pozostawiając tylko niejasne wspomnienie anarchistyczno-rewolucyjnej atmosfery, jaka przepaja to niewątpliwie najbardziej wykończone dzieło Brzozowskiego".

16 Zob. K 109: „Musiałem stwierdzić, że wznowienie Płomieni jest czynem kulturalnie wartościowym, że powieść jest w roku 1947 tak samo czytelna, jak była w roku 1934".

17 Zob. K 109: „Dzisiejszy czytelnik polski podświadomie wprost porównuje konspiracje Narodnej Woli z konspiracją ostatniej wojny. Wyścig Michała i jego towarzyszy z carską policją jakże wyraźnie przypomina konkursy w przebiegłości i sprycie uprawiane wobec Gestapo".

18 Zob. Wspótcześni polscy pisarze i badacze literatury. Stownik biobibliograficzny. T. 4. Oprac. zespół pod red. J. Czachowskiej, A. Szałagan. Warszawa 1996, s. 354. 
Zdaliśmy sobie sprawę $\mathrm{z}$ tego [...], że klucz zrozumienia tak dziwnych dla nas niekiedy reakcji radzieckiego człowieka winien być odszukiwany w czasach jeszcze carskich, w psychice Rosjanina, modyfikującej się w zależności od ustroju społecznego, ale posiadającej pewne cechy zasadnicze, niezmienne. Wydaje mi się, iż nie nazbyt daleki będę od prawdy, gdy powiem, że w tej chwili istnieje ogromny głód wiadomości o Rosji [...]; o cechach zasadniczych tego narodu: o jego charakterze, historii, talentach [...].

Płomienie dostarczają właśnie pewnej sumy wiadomości o jednym z najciekawszych okresów historii Wszechrosji i o jednej z najciekawszych grup rosyjskich. Jest znamienne, jak daleko Brzozowski [...] potrafił przerwać manierę narodowego milczenia lub pisania o Rosji w sposób możliwie pejoratywny, co w żadnym razie nie ułatwiło wzajemnego poznania się i zbliżenia. Brzozowski, zgodnie ze swoimi przekonaniami socjalistycznymi, nader starannie odróżnia naród rosyjski od carskiego reżimu [...].

I oto Brzozowski dokonuje posunięcia bardzo ryzykownego. Tworzy dzieło, w którym Rosjanie zasadniczo okazują się lepsi niż Polacy [...]. Opisuje bodaj najmniej wartościową grupe społeczną polską i zestawia ją $z$ bardzo wartościowym, wysoce inteligentnym, żywym, ruchliwym, bardzo ideowym środowiskiem rosyjskich grup rewolucyjnych, zwących się Narodną Wolą [...]. Można podziwiać tylko śmiałość Brzozowskiego, który zdecydował się [...] podjąć w tak radykalny sposób problem przyjaźni, współpracy, nawet jedności rewolucyjnej polsko-rosyjskiej.

Ten właśnie motyw jest dla dzisiejszego czytelnika szczególnie frapujący. Dla jednych frapujący w sposób pozytywny, afirmujący - dla innych negatywny, wrogi; dziś jednak dla wszystkich - istotny. [K 109-111]

Zacytowany fragment doskonale pokazuje: jak Koźniewski poszukuje ścieżki interpretacyjnej, która pozwoliłaby połączyć Płomienie, symbolizujące lata młodzieńczych fascynacji rewolucyjną lewica, ze współczesnością, w której owo dziedzictwo musi ulec przewartościowaniu; jak zachować tożsamość osoby sympatyzującej z komunizmem w obliczu radykalnej zmiany, jaka przyniosła wojna i okres tuż po jej zakończeniu. Wznowiona powieść Brzozowskiego jest właśnie tą drogá, która pozwala Koźniewskiemu bezpiecznie przeprawić się między latami przedwojennymi i powojennymi. W przytoczonym fragmencie udaje mu się ugrać jeszcze jedno: próbuje on osłabić negatywne nastroje panujące w społeczeństwie, żywione wobec Rosji radzieckiej i wprowadzanej pod jej auspicjami zmiany politycznej, odwołując się do najchlubniejszych kart historii tego kraju z czasów carskich, która w porównaniu z postawami Polaków w tymże okresie okazuje się dojrzalsza, bardziej nowoczesna i bohaterska. Jednakże, podobnie jak u Adamczewskiego, owa rozprawa $z$ samym sobą nie przebiega łatwo i nie ogranicza się do radykalnego zerwania $\mathrm{z}$ duchami przeszłości. Uznając rolę Brzozowskiego w budowaniu tożsamości lewicy polskiej za problematyczną, nie chce Koźniewski wyrzucić jego osoby i tekstów na śmietnik historii. Dlatego też pod koniec recenzji ponownie daje wyraz swojemu rozdarciu:

Maniera pisarska Brzozowskiego, owo publicystyczne poetyzowanie, owa gonitwa myśli i koncepcji, nie ujarzmiona żadnymi rygorami porządku, logiki rozumowania - sprawia, iż właściwie te wszystkie pozycje sa już dziś nieczytelne. Sens myśli Brzozowskiego odszyfrowany musi być z trudem niemałym. Jest to pisarz-publicysta piekielnie zawiły. Prócz właściwej temu czasowi maniery zawinił tu niewątpliwie fantastyczny temperament pisarski tego schorowanego człowieka. Wydaje się, iż jego erudycja przerosła możliwości czasowe jej uporządkowania. Brzozowski po prostu umarł za wcześnie, a pisał po to, by - zgodnie ze swą postawą obca jakiejkolwiek neutralności - wziąc udział w toczącej się podówczas walce myśli i kierunków. Roznosiło go - i ślady tego niespokojnego ducha widać w konstrukcji jego artykułów, rozdziałów książek, paragrafów pism. „Wir idei” prześladował tego człowieka; pogoń myśli nie pozwalała mu przeprowadzić jasnego i chłodnego wykładu. Wyrzucał z siebie jak wulkan lawinę słów i zdań, w potopie których, wśród rzeczy zgoła niepotrzebnych, zwykłego śmiecia, dość często wyłowić można kruszce myśli i koncepcji ciekawych, niekiedy wręcz drogocennych. [K 111-112] 
Artykuł zakończony jest jednak zastrzeżeniem: wydanie Płomieni nie powinno wywoływać nadmiernego optymizmu, należy ostrożnie podchodzić do pomysłu reedycji kolejnych pism Brzozowskiego. Takie postawienie sprawy świadczy o rozdarciu między sympatią dla idola intelektualnego $z$ lat młodości a partyjną wykładnia jego dzieł ${ }^{19}$.

$\mathrm{W}$ podobnym tonie, ale $\mathrm{w}$ zupełnie innej poetyce, utrzymana jest kolejna $\mathrm{z}$ recenzji Płomieni, tym razem pióra Janiny Kulczyckiej-Saloni, zamieszczona w „Kuźnicy" z 1948 roku $^{20}$. Swoje powojenne zainteresowanie Brzozowskim uzasadnia autorka koniecznością rozprawienia się $\mathrm{z}$ charakteryzującą go niejednorodnością myślową, która zaznaczyła się w okresie międzywojennym i potrafiła sprowadzić na manowce niejednego młodego człowieka sympatyzującego z komunizmem (KS 3). Choć twórca recenzowanej powieści znany jest przede wszystkim $z$ dzieł publicystycznych i filozoficznych, które miały największy wpływ na czytelników, to uwagi - zdaniem Kulczyckiej-Saloni - wymaga także jego dorobek literacki. Od samego początku autorka twierdzi, że pod względem artystycznym Płomienie są powieścią nieudaną ${ }^{21}$. Przekonanie to argumentuje antyrealistycznością, „próżnią topograficzną, publicystycznością, jednowymiarowością postaci, brakiem przedstawienia ewolucji idei narodnickiej. Po tym wyliczeniu Kulczycka-Saloni nadmienia:

[...] Płomienie mają te wszystkie zalety, które może dać postawa entuzjastycznego wielbiciela i wyznawcy, postawa głębokiego przejęcia się światopoglądem, stylem życia, typem psychicznym reprezentowanym przez narodników i pełnego sympatii współprzeżywania tego wszystkiego, co stanowiło treść ich życia. Jeśli książce tej brak dystansu epickiego w stosunku do bohaterów i reprezentowanych przez nich spraw, to ma ona za to najgłębszy liryczny współdźwięk z nimi. [KS 4]

Całość recenzji skupia się wokół sposobu, w jaki Brzozowski przedstawia działania Narodnej Woli. Podjęcie tego tematu sprawia, że w oczach Kulczyckiej-Saloni Płomienie sa powieścią niejednorodną. Po pierwsze bowiem Brzozowski „zgodnie $\mathrm{z}$ impresjonistyczną maniera swej epoki roztapia wszystko $\mathrm{w}$ jakiejś mgławicy nastrojów, przeżyć, psychologizowania, odtwarzając przypuszczalnie nastroje swoich bohaterów" (KS 4); nie zachowuje zgodności zdarzeń powieściowych z wydarzeniami historycznymi ani nie przestrzega zasad realizmu. Po drugie, w warstwie ideowej,

Tekst ten nabiera innego sensu, gdy zdamy sobie sprawę, iż autor był wieloletnim współpracownikiem Ministerstwa Bezpieczeństwa Publicznego. Nie przekreśla to, z mojego punktu widzenia, możliwości uznania analizowanego artykułu za rozliczeniowy, jednakże każe zachować spory wobec niego dystans. Trudno debatować nad szczerością żywionej postawy. Uwagę tę umieszczam na marginesie, gdyż w tym miejscu interesuje mnie przede wszystkim analiza tekstowa. Warto jednak zastanowić się, w jakim stopniu współpraca $z$ tajnymi organami państwa wiązała się z doświadczeniem historycznym, w jakim był to przejaw koniunkturalizmu, a w jakim postawa taka wpływała na szczerość wypowiedzi krytycznych. Zob. J. Si e d l e c k a, Kryptonim „Liryka”. Warszawa 2009. „Kuźnica”, której redaktorem naczelnym był S. Żółkiewski, od samego początku przejawiała jasno określoną linię programową, jej podstawę stanowił marksizm. Skierowana była wprawdzie do szeroko rozumianej lewicy, jednak niezmiernie mocno propagowała bliski władzy model literatury. „Twórczość” z kolei, na której łamach tekst swój opublikował Koźniewski, miała bardziej otwarty charakter, a jej pogląd na literaturę w nowej rzeczywistości był bardziej wyważony, nad czym czuwał K. Wyka, nb. sam piszący przed wojną o Brzozowskim. Zob. Sza r u ga, op. cit., s. 216-218.

21 Zob. KS 3: „Ponieważ nie sposób przyznać tej powieści wysokich zalet artystycznych, przynajmniej w naszym rozumieniu, wyróżnienie to musimy przypisać jej tematowi”. 
powieść ta wychwytuje w Narodnej Woli to samo, na co zwracał uwagę Lenin ${ }^{22}$, a więc „podział, który był konsekwencją ideologii indywidualnego terroru i jego teoretycznego uzasadnienia”.

Wytwarzał on [tj. podział] grupę bohaterów ofiarników, którzy poświęcali swe życie służeniu sprawie. Życie takiego bohatera było święte i czyste, wolne od wszelkiej egoistycznej myśli, od dążenia do filisterskiego szczęścia, czyn bohaterski zaś i śmierć z rąk tyrana były tego życia pięknym zakończeniem. Poza tymi bohaterami-ofiarnikami istnieje już tylko bierna masa, o której wyzwolenie walczy się, masa podziwiająca swego bohatera i oczekująca od niego czynu. [KS 4]

Jeżeli autorka przywołuje postać Lenina, to wyłącznie po to, żeby uzasadnić własne prawo do wyrażania pochlebnych opinii na temat Płomieni, a takie w recenzji się pojawiają. Kulczycka-Saloni - w przeciwieństwie do Adamczewskiego i Koźniewskiego - stara się uniknąć wpisania w tekst swojego emocjonalnego nastawienia do filozofa. Mimo to ma trudność nie tyle $z$ dookreśleniem stanowiska zajmowanego wobec recenzowanej powieści, ile $z$ koniecznością przeanalizowania własnych zapożyczeń intelektualnych. Podobnie jak wcześniej omawiani autorzy, Kulczycka-Saloni zapoznała się przed wojną z myślą Brzozowskiego. Świadectwem tego zainteresowania jest chociażby artykuł z „Ruchu Literackiego” z 1935 roku $^{23}$. Choć recenzentka za wszelką cenę stara się ukryć swoje zaangażowanie w przedmiot opisu, to pojawiają się wewnątrztekstowe znaczniki pozwalające sądzić inaczej. Kulczycka-Saloni bardzo dużo uwagi poświęca przedstawieniu światopoglądu i emocji bohaterów Płomieni. Robi to z niezwykłą pasją, o czym zaświadcza nie tylko ilość miejsca poświęcona każdemu z nich, ale także leksyka, wyrażająca uczucia, np.: „namiętność”, „nienawiść”, „szaleńczy”, „głębokie piękno”, „potężny”. Kładąc nacisk na emocjonalną i ideową warstwę utworu Brzozowskiego, Kulczycka-Saloni stara się wydobyć te elementy, które ukazują trudności i przeszkody stojace na drodze do uczynienia $z$ komunizmu zwycięskiej doktryny ${ }^{24}$. Wprawdzie nie ma w tej recenzji bezpośredniego nawiązania do pokolenia międzywojennego i jego doświadczenia wojny, ale pośrednio zostało ono wpisane w historię działaczy Narodnej Woli ${ }^{25}$.

W swojej konkluzji i wymowie ogólnej recenzja Kulczyckiej-Saloni nie pozostawia pola do dyskusji, nie ma tu otwartego zakończenia, lecz jest to tekst zamyka-

Sporo miejsca na początku swojego artykułu poświęca autorka niekorzystnej wizji Narodnej Woli i jej działaczy w literaturze europejskiej.

23 J. Ku l c z y c k a - S a l o n i, Z badań nad twórczością Stanisława Brzozowskiego. Monografia Bogdana Suchodolskiego i praca Jerzego Brauna. (Rec.: B. S u c h o d ols ki, Stanisław Brzozowski, rozwój ideologii. Warszawa 1933. - J. Bra un, Metafizyka pracy i życia. Rzecz o Stanisławie Brzozowskim. Warszawa 1934). „Ruch Literacki” 1935, nr 2. Zob. też artykuł tej autorki Na marginesie książki o Stanisławie Brzozowskim zamieszczony w „Poloniście” (1934, nr 5).

24 Zob. KS 4: „W uczestnikach Narodnej Woli podkreśla [Brzozowski] przede wszystkim potężna, skupioną siłę, jakieś ześrodkowanie całej psychiki na jednej sprawie. Każdy "narodowolec" to człowiek niezwykły, wywierający ogromny, czarodziejski niemal wpływ na otoczenie, urzekający swoją osobowością".

25 Zob. KS 4: „Nastrój walki [...] oddany jest w sposób sugestywny i przekonywajacy. Mamy dwie strony walczące: policję oraz niewidzialnych i nieuchwytnych burzycieli porządku na tle przerażonej ludności "cywilnej", pozornie neutralnej, w rzeczywistości jednak pełnej sympatii dla rewolucjonistów mimo strachu przed represjami”. 
jący, dający jasny komunikat, w jaki sposób należy czytać nie tylko historię ruchu rewolucyjnego w Rosji, ale także samo dzieło Brzozowskiego - czego wyraz stanowi następujący fragment wieńczacy analizowany artykuł:

nie dał [Brzozowski] dziejów Narodnej Woli, tylko jej le g e n d ę, zrodzoną z głębokiego dla niej entuzjazmu. Przy tej postawie nie mógł naturalnie zająć postawy krytycznej, nie mógł dostrzec w tym ruchu jego pierwiastków wstecznych, cały nacisk położył na jasne strony „narodniczestwa”, te właśnie, które Lenin scharakteryzował jako wysunięcie ogólnodemokratycznych postulatów i walkę przeciwko wszelkim pozostałościom średniowiecza i pańszczyzny. [KS 4; podkreśl. P. R.]

W latach 1945-1948 w omawianych pracach dominuje postawa rozrachunku z przeszłością, często powiązana $\mathrm{z}$ rozliczeniami długu intelektualnego zaczerpniętego jeszcze w Dwudziestoleciu międzywojennym. Obok tych tekstów pojawiają się nieliczne, ale dobitne w swym przekazie artykuły próbujące powołać Stanisława Brzozowskiego na patrona nowych czasów. Właśnie taki charakter ma szkic Ideologia Brzozowskiego a chwila obecna, zamieszczony w pierwszym numerze „Zdrojów Sztuki, Literatury i Nauki” z 1945 roku $^{26}$. Jego autor - Czesław Latawiec ${ }^{27}$, podobnie jak wspominane już osoby, nie zainteresował się Brzozowskim dopiero po wojnie. W roku 1926, mając 24 lata, opublikował na łamach „Nowych Wici” pracę zatytułowaną Żeromski a Brzozowski ${ }^{28}$. Ten młodzieńczy tekst, utrzymany w duchu bezkrytycznej apologii, jest w gruncie rzeczy streszczeniem najważniejszych poglądów filozofa. Według Latawca był on typem krytyka-prokuratora, opanował umiejętność syntezy różnych prądów filozoficznych, charakterystyczna była dla niego autokreacyjność podmiotu i traktowanie świata zewnętrznego jako materiału, w którym podmiot może realizować swój potencjał twórczy. Podkreślona zostaje przez autora anarchizująca tendencja w pismach Brzozowskiego, która nie mogła się w pełni zrealizować ze względu na rozwiniętą w jego przypadku filozofię pracy. W zakończeniu Latawiec porusza problem „nawrócenia” młodopolskiego filozofa, biorąc je za dobrą monetę i traktując jako nieuniknioną konsekwencję drogi myślowej Brzozowskiego 29 .

O prawie 20 lat późniejszy tekst, pisany w zupełnie nowej rzeczywistości, utrzymany jest w podobnym, aprobatywnym i bezkrytycznym tonie. Rozpoczyna go, tak

Według informacji zaczerpniętych z Centralnego Katalogu Czasopism Polskich 1801-1950 Biblioteki Narodowej wyszedł tylko jeden numer tego czasopisma z polecenia Poznańskiego Urzędu Wojewódzkiego, Wydziału Kultury i Sztuki Związku Zawodowego Literatów w Poznaniu.

Zob. biogram Cz. Latawca autorstwa L. Sł o w in s k i e go (w: Stownik badaczy literatury polskiej. Red. J. Starnawski. T. 2. Łódź 1998, s. 274-276).

Cz. La t a w i e c, Żeromski a Brzozowski. „Nowe Wici” 1926, nr 1 . Z danych zamieszczonych w Centralnym Katalogu Czasopism Polskich 1801-1950 Biblioteki Narodowej wynika, iż ukazały się trzy numery czasopisma, wszystkie w 1926 roku, w Poznaniu, nakładem Koła Polonistów. Redaktorem naczelnym był S. Balicki, redaktorem odpowiedzialnym Latawiec. Warto zaznaczyć, że Nowy Korbut jako lokalizację artykułu podaje „Nowe Treści”, a takiego czasopisma nie znalazłem w przywołanym tu katalogu. Wszystko wskazuje na to, że zaszła pomyłka.

29 Na podstawie dostępnych materiałów, w tym wspomnianej noty biograficznej, trudno powiedzieć cokolwiek pewnego na temat międzywojennych poglądów politycznych Latawca. Praca z 1926 roku nosi wprawdzie wyraźny ślad wpływu myśli konserwatywnej i katolickiej, nie da się jednak zaliczyć tej pracy do pism inspirowanych myślą nacjonalistyczną. Również fakty z życia Latawca nie daja szansy na określenie jego postawy ideowej. 
jak w przypadku artykułu autorstwa Andrzeja Trzebińskiego, passus wskazujący na wielkie zadanie, jakie stoi przed Polakami u progu wolności:

Nie ulega najmniejszej wątpliwości, że naród polski znajduje się obecnie na rozdrożu, jakiego dzieje dotychczas nie znały. Stoimy w obliczu nowej rzeczywistości, narzuca się nam konieczność przewartościowania wielu wartości, pożegnania się z całą mocą złudzeń i nałogów myślowych, jako też zdobycia nowych sprawdzianów, nowych drogowskazów życiowych. Mało kto jednak zdaje sobie sprawę, że nikt ich tyle nie jest w stanie dostarczyć, co Brzozowski, niczyja twórczość bowiem nie jest tak aktualna, niczyja nie ma tylu punktów stycznych z chwilą obecną, co jego twórczość. [L 11]

Tekst, z którego pochodzi ten fragment, jest nie tylko próbą zwrócenia uwagi na wyjątkowość momentu dziejowego i na konieczność znalezienia patrona ideowego, który pozwoliłby budować spójną wizję nowej Polski. Stanowi też kontynuację myśli zawartych w przedwojennym numerze „Nowych Wici”. Podobnie jak wtedy, dla Latawca najistotniejszy w pismach Brzozowskiego jest wymóg nieprzerwanej pracy fizycznej, przekształcającej rzeczywistość podług ludzkiej woli, a w działaniu tym stwarzanie nowego podmiotu dziejowego, odpowiedzialnego za siebie i otaczający świat, jednocześnie zaś tworzenie nowego narodu ${ }^{30}$. Poglądy Latawca z 1945 roku cechuje niezachwiana pewność co do własnych racji i przekonanie, że u autora Płomieni można znaleźć wszystko, czego potrzeba człowiekowi, którego zaprojektował komunizm. Artykuł Ideologia Brzozowskiego a chwila obecna jest więc kontynuacją dawniejszych wątków i ich uzupełnieniem o to, co nabiera mocy w nowej rzeczywistości i co wydawało się autorowi zgodne z ówcześnie dominującymi przekonaniami społeczno-politycznymi. Chodzi m.in. o krytykę szlachetczyzny jako zgubnego dla Polski modelu stosunków społecznych, których przedłużeniem miały być rządy Piłsudskiego i wywodzącej się od niego sanacji. Krytyka tego ugrupowania opiera się wyłącznie na przesłankach zaczerpniętych z prac Brzozowskiego, a celem pozytywnym owej krytyki jest chęć stworzenia nowego człowieka, o jakim marzył autor Idei. Wiare $\mathrm{w}$ moc przypisaną ludzkości wyraża Latawiec $\mathrm{w}$ iście młodopolskim stylu:

Nie uciekać, nie drżeć i tchórzyć, ale opanować to straszne piekło, poddać je swojej woli, zatriumfować nad nim szerokim, zwycięskim śmiechem i róść w moc, w nieskończoną potęgę. Wypowiedzieć żywiołom walkę, skuć je, niech warują jak psy, i podporządkować woli ludzkiej - to jest jedynie godne człowieka. [L 13]

Dla Latawca idea budowy Polski komunistycznej, gdzie podstawa jest przemysł, uzależnienie natury od rozumu ludzkiego i jego wytworów, musiała się wydawać niezwykle bliska postulatom, jakim hołdował sam Brzozowski. Siłę uzdrowicielska widział w nowej, biologicznie pojmowanej ludzkości, której urzeczywistnieniem był proletariat (L 13).

Trzeba by zwrócić uwagę na jedną, szczególnie rzucającą się w oczy właściwość tekstu. Otóż w idei nieograniczonej mocy człowieka, opartej na przesłankach biologicznych, nie doszukuje się autor zalążków faszyzmu. W żaden sposób nie wiąże

30 Zob. L 13: „Marzył on [tj. Brzozowski], że proletariat sięgnie po najwyższe zdobycze wiedzy i techniki i za ich pośrednictwem wykuje nową rzeczywistość [...]. Proletariat przekuje społeczeństwa na samowładnie rządzące sobą organizmy pracy, takim organizmem będzie Polska, ojczyzna prawdy, klasyczny kraj samorządu człowieka”. 
Brzozowskiego $\mathrm{z}$ nacjonalizmem ani $\mathrm{z}$ wiarą $\mathrm{w}$ siłę rasy, co było $\mathrm{w}$ tamtym czasie często podnoszoną sprawą. Być może, to owa ufność we własną interpretację zagadnienia, odmienną od przyjętej później wykładni, spowodowała, że Latawiec nie zabierze już głosu w dyskusji toczącej się w kolejnych latach. Bezgraniczna wiara badacza w ideały młodości, nie zachwiana doświadczeniami wojennymi, okazała się wyjątkowa na tle ówczesnych wypowiedzi. W takiej nieugiętej postawie widać jednak pewną dozę fanatyzmu. Obydwa teksty, przed- i powojenny, sa niezwykle agresywne w wymowie, nie stwarzaja pola do debaty. W swojej bezkompromisowości Latawiec nie zauważa, że popada w koleiny utarte w dyskusjach prowadzonych w latach dwudziestych XX wieku. To, z czym starali się sobie poradzić Adamczewski czy Koźniewski, a więc idea siły, biologizmu, specyficznie pojętego nacjonalizmu, dla Latawca jest niezbitym dowodem na paralelność doktryny komunistycznej i koncepcji głoszonych przez młodopolskiego filozofa. Na tle dyskusji toczonych w pierwszych trzech powojennych latach postawa prezentowana przez krytyka należy do rzadkości, sposób zaś przejścia między czasami przed- i powojennymi okazuje się karkołomny. Nawet próby wplecenia tak ważnych dla komunistów haseł, jak proletariat czy przemysł, w tkankę myśli Brzozowskiego nie mogły uchronić Latawca przed możliwym posądzeniem o sprzyjanie poglądom reakcyjnym. Obrana przez niego droga rozliczenia się z ideami młodości, a właściwie ich podtrzymania czy nawet wzmocnienia, okazała się w tamtych czasach ślepa uliczka, gdyż była zbyt bliska założeniom faszystowskim, odpowiedzialnym za gehennę drugiej wojny światowej.

Autorzy przywołanych przeze mnie tekstów, pozostając - chcąc czy nie - uczniami Brzozowskiego, przyswoili sobie imperatyw kształtowania siebie i świata podług woli, odpowiedzialności za swoje życie. Jednak idee nie zawsze można przekształcić w czyn, a ludzkie działania ograniczone są przez najróżniejsze czynniki. Jak pisać o jednostkach, na których oczach rozgrywały się dramatyczne wydarzenia? Nie stanowi problemu uznanie, że kompromisowa postawa tych osób wynikała $z$ chęci przypodobania się nowej władzy. Łatwo przypiąć im łatkę cyników, karierowiczów bądź zdrajców ideałów własnej młodości ${ }^{31}$. Klasyfikacja podług tych kategorii jest jednak - w moim odczuciu - niedopuszczalna. Analizując teksty omawianych autorów, należy wziąć pod uwagę warunki, w jakich były one tworzone, a zarazem stosować zasadę ograniczonego zaufania. Nietrudno bowiem popaść w pułapkę zarówno uproszczonej psychologizacji, jak i bezkontekstowej analizy materiału. Najlepszym, choć z pewnością niedoskonałym rozwiązaniem jest spojrzenie na te artykuły jak na wyraz przekonań, chęć komunikacji ze światem. Ich strukturę należy zaś badać wielostopniowo, przy użyciu wszelkich narzędzi wypracowanych przez literaturoznawstwo. Trzeba też dostrzec ideowy i pragmatyczny charakter

31 W ciekawy sposób o przeżyciach pisarzy zaraz po wojnie pisze G. P. B ą biak w Doświadczeniu totalitarnym polskich twórców kultury po 1945 roku (na podstawie dzienników Iwaszkiewicza, Nałkowskiej, Szczepańskiego, Lechonia), zamieszczonym w zbiorze Doświadczenie i dziedzictwo totalitaryzmu na obszarze kultur środkowoeuropejskich (Red. J. Gos zczyńs ka, J. Królak, R. Kulmiński. Warszawa 2011). Autor krytykuje praktykę pewnych środowisk historyków, którzy wyłącznie na podstawie dokumentów szafują wyrokami. Zamiast tego proponuje on zwrócenie uwagi na zawiłość losów jednostek wplątanych w Wielką Historię. 
wypowiedzi. Jednocześnie powinno się przyjrzeć ich uwikłaniom w grę różnorodnych sił społecznych, politycznych i kulturalnych - epok, w których powstawały.

Zrozumienie dyskusji o Brzozowskim jako istotnego elementu życia społecznego i kulturalnego nie byłoby możliwe bez wzięcia pod uwagę pism ukazujących się poza granicami kraju. Analiza głosów dobiegających z oddalenia pozwala wprowadzić dodatkowe argumenty, rzucające więcej światła na konkretne postawy, wybory i wyznawane poglądy. Właśnie w tym kontekście należy postrzegać artykuł Stefanii Zahorskiej Myśli o Brzozowskim, wydrukowany w 1945 roku w Londynie. Jak podaje Maciej Urbanowski, są to fragmenty większej pracy, która nigdy nie została opublikowana (zob. Z 249). Tekst Zahorskiej wyraźnie dzieli się na dwie części: jedną $z$ nich jest wnikliwa interpretacja najważniejszych dla Brzozowskiego problemów filozoficznych, $\mathrm{z}$ teoria poznania na czele, druga to próba powiązania idei autora Ptomieni z burzliwymi wydarzeniami 1945 roku. Przy tym drugim aspekcie pragnę się na chwilę zatrzymać. Jego dokładniejsza analiza jest niezwykle ważna, jeżeli chcemy zrozumieć postawy i poglądy twórców piszących w Polsce i poza jej granicami. Podobnie jak ci pierwsi - Zahorska doskonale uświadamia sobie niezwykłość momentu historycznego, w którym znalazł się świat, a szczególnie Polska ze swoim geopolitycznym położeniem. W takiej sytuacji, analogicznie do pozostałych intelektualistów, autorka zastanawia się nad przemianami ideowymi i możliwością ustanowienia dla nich patrona. Brzozowski nadaje się do tego doskonale nie tylko ze względu na swoje marksistowskie inspiracje, ale także dlatego, że, ,jak [...] żaden pisarz polski, jest związany z kulturą europejska, żyje myślą europejską wszystkich czasów, wszystkich krajów, wszystkich dziedzin twórczości” (Z 260). Postać i filozofia Brzozowskiego zarówno miałyby patronować rodzimym dyskusjom wokół zagadnienia lewicy, jak i wpisać je w szerszy, europejski krag. Postawa taka nie może dziwić u osoby przebywającej na emigracji, patrzącej na polskie życie polityczne, kulturalne i naukowe z szerszej perspektywy. Ta pozycja oddalenia daje Zahorskiej niezaprzeczalną przewagę nad rodakami pozostającymi w kraju. Uświadamiając sobie tę wyjątkowość, autorka stwierdza:

faktem jest, że nasze życie emigracyjne przechowało niemal bez zmiany ten przedwojenny typ myślenia i tę postawę cząstkową, „bezwyznaniową”, na wewnątrz i na zewnątrz sceptyczną. W Kraju musiało się wiele zmienić. I może właśnie jednym $z$ dowodów tej zmiany, dążenia do scalenia poglądów, do uświadomienia sobie ogólnej postawy wobec życia, jest zwrócenie się do Brzozowskiego. [Z 263]

Stanowisko Zahorskiej jest, $\mathrm{z}$ jednej strony, obce, $\mathrm{z}$ drugiej zaś bliskie takim osobom, jak Adamczewski, Koźniewski czy Kulczycka-Saloni. Zahorska widzi bowiem w socjalizmie Brzozowskiego ogromna wartość, element, który powinno się uwzględnić w programie ideowym nowej Polski, na co kładzie akcent w przytoczonym fragmencie. Jednocześnie utrzymuje, że nie może być to socjalizm w wydaniu narzucanym przez Związek Radziecki. Powołuje się tu na samego Marksa, twierdząc:

Dla Marksa socjalizm był nieodłącznie zespolony z demokracją, i budował on wizję rozwoju socjalistycznego ustroju na podłożu istniejącej demokracji. Choć hasła socjalistyczne były motywem rewolucji rosyjskiej, choć szła ona początkowo po tej linii, w dalszym jej rozwoju dominujące okazały się inne czynniki, które zalały pierwotne ideologiczne, socjalistyczne tendencje. Unicestwiły je nie dlatego, że taka logika tkwiła w samej ideologii, ale dlatego, że materiał ludzki, stopień jego cywilizacji, tradycje 
historyczne, w ogóle całość materialnego i psychicznego poziomu tego olbrzymiego i niejednolitego zbiorowiska ludzkiego narzucił realny bieg jego historii. [Z 264] $]^{32}$

Postawa Zahorskiej wobec komunizmu rosyjskiego jest jednoznaczna i odbiega od postaw wyrażanych w tym samym czasie w kraju. Autorka posługuje się typową dla późniejszych rewizjonistów argumentacją odwołującą się do źródeł ideowych, udowadniając w ten sposób, że droga radziecka stanowiła owej myśli wypaczenie ${ }^{33}$. Nie jest to jednak postawa odrzucenia socjalizmu jako takiego. Wręcz przeciwnie. Zahorska, krytykując jego wypaczenia - np. determinizm, nadmierne upartyjnienie czy wreszcie złączenie go z dziejami Rosji, przyznając, że „socjalizm poniósł także wielką porażkę, że nie spełnił wszystkich pokładanych weń nadziei” (Z 265), zaznacza równocześnie:

Ogrom dokonań socjalizmu i jego wpływ na bieg rozwoju może być dlatego przeoczany, że stał się on własnością całych społeczeństw, w ich obrębie także przeciwników socjalizmu. Nie tylko zmieniło się pod jego wpływem położenie klasy robotniczej, nie tylko sprawy gospodarcze doznały przemian pod tym naciskiem, ale cały nasz styl życia i myślenia jest pod świadomym lub nieświadomym wpływem socjalizmu, podobnie jak wizja przyszłości i jej planowanie. [Z 264-265]

Na taką recenzję wystawiona socjalizmowi mogła pozwolić sobie jedynie osoba przebywająca na emigracji, wyposażona w inne doświadczenie niż autorzy krajowi, których losy wojenne i sytuacja po 1945 roku zmusiły, pod wpływem nacisku i cenzury, do umiejętnego pytania o sens socjalizmu Brzozowskiego. Furtka dla wyrażenia nieortodoksyjnych myśli było przybranie postawy sceptycznej, uchylającej się od udzielania jednoznacznych odpowiedzi. Trudno twierdzić w tym wypadku, że twórcy krajowi popadali w swego rodzaju koniunkturalizm. Zapewne nie mogli - tak jak Zahorska - otwarcie pisać o własnych przekonaniach, nie wolno im wszakże zarzucić nieszczerości. Obie strony pokazują bowiem schizmatyczną rolę Brzozowskiego jako marksisty. W kraju nieprawowierność tę częściej interpretowano jako kierowanie się w stronę faszyzmu, Zahorska zaś uznaje ją za odżegnanie się od tendencji totalitarnych. W jej ujęciu socjalizm Brzozowskiego powinien być szczepionka przeciwko wypaczeniom stalinowskiego komunizmu (zob. Z 266). Swoje rozważania autorka kończy mocnym słowami:

Przyszłość, która rysuje się przed nami, jest bardziej tragiczna aniżeli wszystko, o czym mógł myśleć Brzozowski. Jeżeli wojna zakończy się pokojem, zapewniającym nam istotną niepodległość, wrócimy do Kraju, który trzeba będzie budować od nowa, w warunkach najtrudniejszych. Jeżeli pokój odbierze niepodległość nam i Europie Środkowej, walka - choć w zmienionej formie - będzie trwała dalej. Europa będzie się broniła przed tym, aby spóźniony proces rozwojowy Rosji nie stał się przyczyną upadku kultury europejskiej. Będzie się broniła przed niwelacją w dół. [...]

Koniec wojny nie będzie dla nas w żadnym wypadku końcem trudów. Bardziej niż kiedykolwiek

Zob. też Z 263-264: „Slogan o bankructwie socjalizmu jest dziś dość rozpowszechniony. Podstawą jego jest przede wszystkim to, co dokonało się w Rosji jakoby w konsekwencji rewolucji socjalistycznej. [...] Rosja nie jest dziś zagadnieniem socjalizmu, tym mniej zagadnieniem międzynarodowego socjalizmu, jest przede wszystkim zagadnieniem rosyjskim, jest zagadnieniem przejścia od specyficznego rosyjskiego feudalizmu do specyficznego rosyjskiego imperializmu [...]".

33 Podobnie pisze L. Koła k ow s ki we wstępie do Głównych nurtów marksizmu (t. 1. Wprowadzenie K. Pomian. Warszawa 2009). Jego zdaniem jednak, droga radziecka bezpośrednio wynikała z założeń komunizmu. 
trzeba nam mocnej woli. Trzeba nam takich poglądów, które kierowałyby naszym wysiłkiem, które byłyby ugruntowaniem naszej niezłomnie aktywnej postawy.

Filozofia Brzozowskiego - to sa propozycje idące w tym kierunku. Propozycje do przemyślenia i uzupełnienia. [Z 268]

Nie sposób odmówić Zahorskiej ogromnej przenikliwości politycznej. Autorka doskonale zdawała sobie sprawę, jakie są możliwości czekające kraje Europy Środkowej, w tym Polskę, w sytuacji gdy wpływy w tej części świata przejmie Rosja radziecka. Zahorska patrzyła jednak z odmiennej perspektywy. Nie wolno zarzucić twórcom krajowym, że nie uświadamiali sobie swego położenia. Byli zupełnie inaczej doświadczeni i poddani innym naciskom. Prezentowanych przez nich stanowisk nie można więc odczytywać jako naiwności politycznej i życiowej. Wręcz przeciwnie. Należy ich zrozumieć, gdyż pisali oni o sobie i o nowej rzeczywistości, w której przyszło im żyć, z jej wnętrza. Ukazywana przez nich postawa ideowa i życiowa nie była wynikiem wewnętrznego zakłamania, ale brała się z konkretnych doświadczeń. Łatwo orzec osobom nie wplatanym w ówczesny bieg wydarzeń, że w tym starciu Zahorska miała rację i że stosowane przez nią interpretacje okażą się żywe 10 lat później. Nam, ludziom patrzącym $z$ oddali, z piedestału Historii dokonanej, szafowanie takimi ocenami przychodzi $z$ łatwością. Tworzący w tamtym czasie nie mogli wiedzieć, jak osądzą ich potomkowie, musieli działać, pisać i żyć w określonych warunkach społecznych, historycznych i kulturowych.

Środowisko emigracyjne było bardzo zróżnicowane, składało się z przedstawicieli rozmaitych opcji politycznych i światopoglądowych. U Zahorskiej widać mocne wpływy wartości socjalistycznych ${ }^{34}$. Nie wszyscy jednak przywiazywali tak wielką wagę do tej właśnie linii ideowej myślenia Brzozowskiego. Przykład stanowi Gustaw Herling-Grudziński, dla którego kluczowym wątkiem w odczytywaniu pism autora Legendy Młodej Polski był postulat - wręcz nakaz - kształtowania siebie i otaczajacego świata podług woli. We wstępie do Filozofii romantyzmu polskiego wydanym w Londynie Herling-Grudziński nawiązuje do tekstu Zahorskiej, podnosząc problem lektury dzieł Brzozowskiego w okresie istnienia Polski Podziemnej (H 270-271). Podobnie jak autorka emigracyjna - uważa, że głoszone przez Brzozowskiego idee wymagają dogłębnego przemyślenia i przeanalizowania w nowym kontekście dziejowym $^{35}$. W jego mniemaniu zachłyśnięcie się twórcą Idei jest powierzchowne i dalekie od zrozumienia podstawowego przewartościowania polskiego romantyzmu. W ujęciu Herlinga-Grudzińskiego rodacy pozostający w kraju ciągle nie pojęli, że przetrwanie narodu musi być uzależnione od życia przepełnionego czynem i pracą, które to kategorie są centralne dla całej filozofii Brzozowskiego.

Poza wspomnianym nawiązaniem do Zahorskiej tekst milczy o nastawieniu autora do zachodzacych w Europie przemian. Można jednak sądzić, że wybranie konkretnej pracy Brzozowskiego i pisanie do niej wstępu miało być w pewnym sen-

Słownik podaje, że autorka została aresztowana w latach dwudziestych za domniemane kolportowanie czasopism Kominternu. Zob. B. D o r o s z, Zahorska Stefania. Hasło w: Współcześni polscy pisarze i badacze literatury. Stownik biobibliograficzny, t. 9 (2004).

35 Zob. H 271: „całokształt filozofii Brzozowskiego pozostanie jeszcze zapewne na długo dla ogółu czytelników, a nawet i badaczy, czymś w rodzaju złomu rudy, w której coraz to odsłania się nowa żyła złota. Czas, warunki, zainteresowania i tendencje sprawiają, że się autora Idei ciągle "odkrywa»". 
sie głosem w dyskusji, zajęciem stanowiska. W swojej Nocie o Brzozowskim Herling-Grudziński nieustannie podkreśla konieczność działania i mężnego zmierzenia się Z „najgroźniejszą nawet rzeczywistością” (H 276). W tej interpretacji Brzozowski urasta do roli tytana walki, który musi stać się wzorem dla Polaków, by ich ojczyzna mogła uzyskać pożądany kształt. Nie da się tego zrobić jedynie w sensie ideowym, ale należy tę rzeczywistość wykuwać w nieustannym działaniu, co podkreśla Herling-Grudziński, przywołując znany fragment z Legendy Młodej Polski:

Tu - oto tu, między fabrycznym młotem a chłopskim pługiem, między proletariuszem-robotnikiem a polską chłopską wsią zaczyna się, poczyna Polska. Tu jest koncepcja nie z bibuły i druku, lecz z ciała i krwi, tu jest młoda Polska, która oto już jest, żyć usiłuje wobec pozaludzkiego i międzyludzkiego żywiołu [...]. [H 274]

Ten heroizm czynu przeciwstawiony jest krytykowanej przez Brzozowskiego Polsce zdziecinniałej, biernej, poddanej szlacheckiej spuściźnie w jej najgorszej odsłonie. W swoim omówieniu filozofii i krytyki literackiej autora Idei Herling-Grudziński wyróżnia dwie ścieżki, którymi może pójść naród: albo podejmie ciężką prace przy budowie nowej rzeczywistości, albo ulegnie bierności szlacheckiej. Pierwsza, choć heroiczna i trudna, jest w jego oczach jedynym możliwym wyborem. Zatem Notę o Brzozowskim należy uznać za ilustrację toczącej się dyskusji nad spuścizną filozofa w powojennej Polsce, a także za świadectwo różnicy zdań i interpretacji dziedzictwa polskiej myśli w środowiskach emigracyjnych. Przykłady Zahorskiej i Herlinga-Grudzińskiego pokazują, że autor Legendy Młodej Polski dzielił i był zarzewiem sporu nie tylko w swojej ojczyźnie, ale też poza jej geograficznymi granicami. Jest to jednak ciągle ten sam spór o to, jak powinny wyglądać nowy świat i nowy człowiek po drugiej wojnie światowej.

Częste w analizowanych tekstach wyprawy w Dwudziestolecie nie tylko miały charakter osobisty i biograficzny, lecz wiązały się także $z$ próbą pisania historii ruchu komunistycznego w Polsce w oparciu o rodzime tradycje, by w ten sposób móc legitymizować nowy porządek ${ }^{36}$. Była to sprawa wielkiej wagi, gdyż pozwalała udowodnić, że polski komunizm i w ogóle początki myśli lewicowej sięgały jeszcze czasów przedwojennych. Twierdzenie takie wydać się musi oczywistością. W tamtym okresie, w latach 1945-1948, był to jednakże istotny element gry politycznej. Obejmowała ona walkę o świadomość ideową w nowej rzeczywistości. Element tej walki stanowił bój o interpretację myśli Brzozowskiego i jego pism, a więc o tożsamość polskiej lewicy rewolucyjnej. Odniosę się do dwóch przykładów pozwalających stwierdzić, jak ważne okazało się szukanie wsparcia wśród przedwojennych intelektualistów o proweniencji lewicowej. Wykorzystywano ich nawet wtedy, gdy daleko im było do komunizmu. puszczać przeszłości na żywioł”. „Krótki kurs WKP $\langle b\rangle$ ” jako opowiadanie mityczne. W: Rytuat i demagogia. Trzynaście szkiców o sztuce zdegradowanej. Warszawa 1992, s. 32-33), traktowała dzieje partii komunistycznych innych niż rosyjska $z$ wyższością bądź zupełnie je pomijała. $Z$ tej perspektywy próba odwoływania się do rodzimych tradycji i ich ponownego ustanawiania nabiera ogromnego znaczenia. 
Wydana w 1947 roku w „Wiedzy i Życiu” praca Ludwika Frydego z przedmowa Ryszarda Matuszewskiego ${ }^{37}$ miała odegrać rolę archetypicznej - lewicowej z ducha - krytyki Brzozowskiego. Artykuł napisany został jeszcze w 1939 roku, nie doczekał się publikacji z powodu wybuchu wojny. Autor rozprawy, oprócz wydrukowanego pośmiertnie tekstu, znany jest $z$ innego szkicu o młodopolskim filozofie, pochodzącego z 1938 roku, w którym dokonuje krytyki jego poglądów i w którym widać zalążki o rok późniejszego artykułu.

Praca Frydego Stanisław Brzozowskijako ideolog inteligencji polskiej oraz wcześniejsza - zatytułowana Brzozowski jako wychowawca ${ }^{38}$ - zawierały argumenty doskonale nadajace się do walki $z$ dziedzictwem ideowym młodopolskiego filozofa, a szczególnie z jego nieortodoksyjnymi odczytaniami Marksa. Nie dość, że nie straciły one na sile w czasie wojny, to w nowej rzeczywistości społecznej nabrały większej wartości. Nie rekonstruując w pełni dowodzenia Frydego, pozwolę sobie wymienić te zarzuty, które mają niebagatelne znaczenie w dyskusji nad dziedzictwem intelektualnym Brzozowskiego zaraz po wojnie. Są to kolejno: mętność stylu, pochwała imperializmu, nadmierny psychologizm i będacy jego konsekwencją subiektywizm, oderwanie od faktów społecznych, a nade wszystko podkreślana nieustannie, jawna bądź ukryta, pochwała mieszczaństwa. Nie darmo tekst z 1939 roku traktuje Brzozowskiego właśnie jako ideologa tej klasy społecznej. $Z$ perspektywy władzy artykuł Stanisław Brzozowski jako ideolog inteligencji polskiej był doskonałym narzędziem w walce ideologicznej. Jeszcze przed wojna wybitny krytyk udowadniał, że autor Legendy Młodej Polski nie tylko nie jest marksistą, nie tylko nie uważa klasy robotniczej za przewodnią siłę ludzkości, ale gloryfikuje inteligencję w jej najbardziej wstecznej i faszystowskiej odmianie. Wszystkie te argumenty pojawiaja się w tekstach Frydego i nie trzeba było w żaden sposób dodatkowo podkreślać ich wymowy. Same w sobie miały bowiem potężną siłę rażenia, która została wzmocniona przez wydarzenia historyczne.

Wydana po wojnie praca to ostra krytyka wymierzona nie tylko pod adresem młodopolskiego filozofa i brzozowszczyków, ale także pod adresem środowiska naukowego zajmującego się dziedzictwem pisarza. Matuszewski, niejako z konieczności, doszukuje się w artykule Frydego odstępstw od przyjmowanej w 1947 roku wykładni marksizmu. Dla przedwojennego krytyka kategorie ekonomiczne były drugorzędne wobec kategorii filozoficznych i społecznych. Błąd ten wytyka Matuszewski nie tyle w celu ujawnienia niedomagań aparatu krytycznego, jakim posługuje się Fryde, ile w celu wskazania, że pewne wydarzenia nie mogły być przezeń odpowiednio zinterpretowane $z$ powodu niedostatecznej wiedzy historycznej. Otwarta krytyka samego Frydego nie wchodziła w grę ze względów taktycznych. Prawdziwym wrogiem był Brzozowski. Nieortodoksyjność Frydego należało więc zamaskować, przypisując mu nieznajomość określonych procesów dziejowych i w ten sposób ratując go przed oskarżeniem o reakcjonizm. Mechanizm naprostowywania nie dość

L. Fryd e, Stanisław Brzozowski jako ideolog inteligencji polskiej. Wstęp R. Matu szew ski. „Wiedza i Życie” 1947, nr 7/8.

38 L. Fry de, Brzozowski jako wychowawca. W: Wybór pism krytycznych. Oprac. A. Bierna cki. Warszawa 1966. 
ortodoksyjnych - z punktu widzenia Matuszewskiego - twierdzeń i przyjętych założeń badawczych najlepiej obrazuje następujący cytat:

Próba określenia przezeń [tj. przez Frydego] Brzozowskiego jako reprezentatywnego ideologa polskiej inteligencji wymaga jednak dzisiaj pewnego dopełnienia. Słuszne wydawałoby się stwierdzenie, że był on typowym ideologiem pewnego tylko odłamu tej inteligencji, w pewnym, dziś już w dużo większym stopniu niż w czasie, w którym powstała praca Frydego, zamkniętym okresie dziejowym. Inteligencki, w sensie oderwania od realnego podłoża i związków z szerszą bazą społeczną, charakter nosiła nie tylko postawa grupy rządzącej Polską od maja 1926 do września 1939, za której odległego myślowego prawodawcę mógł być po części słusznie uważany Brzozowski, ale również i postawa większości jego krytyków, z Frydem włącznie, nie opierających analizy wypowiedzi autora Idei o analizę istniejącego w czasie ich pojawiania się układu stosunków społeczno-gospodarczych, których ideologia ta była wyrazem ${ }^{39}$.

W tym wypadku budowanie wspólnoty przekonań, szukanie poprzedników antycypujących krytykę Brzozowskiego z pozycji komunistycznych - bądź w jakiś sposób jemu bliskich - stawało się dla Matuszewskiego, zresztą nie tylko dla niego, zadaniem ważniejszym niż krytyka. Takie konstrukcje oddzielające swoich od obcych mają wątpliwą wartość epistemologiczną, bezsprzecznie zaś odznaczają się mocą perswazyjną. Budowanie wrogich sobie obozów stanowiło więc cechę zarówno polityki, jak i świata idei. W jednym i drugim wypadku dość szybko można było z funkcji sojusznika zostać przeniesionym na pozycję wroga. Każdy taki ruch był uzależniony od czasowych celów i sposobów tworzenia narracji historycznej ${ }^{40}$.

Sprzymierzeńcem w boju z Brzozowskim okazał się także Wacław Nałkowski, skądinąd przychylny autorowi Idei. Ten wybitny polski geograf i działacz społeczny, zmarły w tym samym roku co Brzozowski, pozostawił po sobie notatki majacce być wstępem do planowanej pracy o Legendzie Młodej Polski. Pierwszą wersję zapisków opublikowano jeszcze przed wojną, w 1938 roku, w „Epoce”, prowadzonej przez Henryka Lukreca. On też, w 1949 roku na łamach „Prasy Polskiej”, wspomina o redagowanym przez siebie przedwojennym piśmie nie tylko jako o wielkim dziele, ale też jako o jednym $z$ nielicznych periodyków, który był w stanie przepowiedzieć wojnę $^{41}$ oraz późniejszą interpretację dzieł Brzozowskiego. Świadczyć o tym miała przywoływana publikacja notatek Nałkowskiego ${ }^{42}$. Znaczenie tych notatek podkreśla przedruk wersji z 1938 roku w tygodniku „Nowa Kultura” (1951, nr 3) ${ }^{43}$.

Forma, w jakiej zostały zapisane uwagi krytyczne pod adresem Legendy Młodej Polski, wskazuje na ich roboczy oraz osobisty charakter. Pojawiające się w nich zarzuty niewiele odbiegają od tych, które stawiane były Brzozowskiemu jeszcze

Inną wersję owych zapisków drukuje „Kuźnica” w 1945 roku, w pierwszym numerze. Lukrec nie tylko nie wspomina o tej publikacji, ale w ogóle nic nie mówi o dwóch wersjach notatek Nałkow-

skiego. Widać tu pewne nieścisłości co do nich i ich losów.

R. Matu s zew s ki, wstęp w: Fry d e, Stanisław Brzozowski jako ideolog, s. 625.

Zob.: „Stopień zgodności z doktryną to tylko jedno z kryteriów pozwalających określić, czy dany utwór zasłużył na miano socrealistycznego. Czasem kryterium to może się okazać zawodne. Tak jak zawodna musiałaby być odpowiedź na pytanie, czy dzieło życia Mao Tse-tunga, Józefa Broz-Tity albo Pol Pota jest, czy też nie jest, socjalizmem - bez uwzględnienia bieżącej polityki ZSRR” (cyt. za: Z. Ła piń ski, Jak wspótżyć z socrealizmem? W: Jak współżyć z socrealizmem. Szkice nie na temat. London 1988, s. 93-94).

H. Lu k re c, W dziesięciolecie zamknięcia „Epoki”. „Prasa Polska” 1949, nr 5, s. 5-6.

L u krec (ibidem, s. 6) dodaje w powojennym tekście, że powierzony mu rękopis zaginął w czasie wojny. 
w latach dwudziestych ubiegłego stulecia. Warto jednakże wspomnieć o krytyce pracy, jaka przeprowadza Nałkowski. W sposób mocny i sugestywny stwierdza:

Skądże wezmą energię do pracy masy źle odżywiane? - Stracą resztki. Te więc resztki muszą być użyte nie na pracę, lecz na walkę o zmianę warunków istnienia. Budzić energię w dzisiejszym ustroju kapitalistycznym jest to wzmacniać wyzysk; bo cóż pomoże energia pracy wobec przewagi kapitału - ona tylko powiększy jego panowanie. To wzdychanie do pracy fizycznej, ten jej kult (zgodnie z tołstoizmem), wyrażający się także w „postępowej” pedagogice, jest reakcją, jest dążeniem do zbydlęcenia, zautomatyzowania człowieka; cały rozwój ludzkości dąży w przeciwnym kierunku, do wyzwolenia się od pracy fizycznej ${ }^{44}$.

Obok wymienionych zarzutów dotyczących krytyki pracy wyłaniają się znane oskarżenia o eklektyzm, szafowanie ocenami, mętność stylu. Nie treść tych notatek odgrywa tu kluczową rolę, lecz sam fakt ich wydrukowania. Pojawiają się one na łamach wspomnianych czasopism w dwóch różnych momentach. W przypadku „Kuźnicy” chodzi o rok 1945, w przypadku „Nowej Kultury” o 1951 rok. Są to więc dwa momenty w politycznej historii Polski o różnej wadze. Publikacja zapisków $\mathrm{w}$ pierwszym numerze programowego periodyku polskiej inteligencji, w okresie silnych walk ideowych, uwidacznia ich wymiar symboliczny. Składaja się one na nowy program powojennej lewicy. Choć nie opatrzone komentarzem, same w sobie stanowią mocny znak obranej drogi. Pięć lat późniejszy druk jest wyłącznie poświadczeniem słuszności podjętych decyzji. Ponowna publikacja zapisków zdaje się dowodzić pojawienia się jakiegoś fermentu ideowego, który miała ona neutralizować. Trudno jednak dociec, o jaki ferment mogło tu chodzić. Fragmenty zamieszczone w „Kuźnicy” okazuja się mniej napastliwe, są raczej rzeczowymi rozpoznaniami, celnie poprowadzoną krytyką. Te znajdujace się w „Nowej Kulturze” zawierają sporą dozę emocji, wydają się poszarpane, niespójne. Dają jednakże jasny przekaz: Brzozowski jawi się jako myśliciel wrogi klasie robotniczej, ideolog imperializmu i wyraziciel interesów burżuazji. Choć przekonanie to trudno byłoby racjonalnie wyjaśnić tylko na podstawie zamieszczonych materiałów, to przesłanie emocjonalne wydaje się klarowne. W ten sposób, powołując się na przedwojenne autorytety Frydego i Nałkowskiego, prowadzono precyzyjnie określana politykę historyczną 45 , w której nie było miejsca dla idei i ludzi pokroju Brzozowskiego.

Wróćmy jeszcze na chwilę do lat 1945-1948 i przypomnijmy kolejną dyskusję sprowokowaną nie tyle pismami Brzozowskiego, ile jego osobą. Jak bardzo niejednoznaczną był on postacią i jak wielkie emocje budził wśród polskiej inteligencji, świadczy kilka krótkich tekstów opublikowanych w latach 1947-1948 na łamach „Nowin Literackich”, poruszających tzw. sprawę Brzozowskiego. Jerzy Wyszomirski, nauczyciel, literat, felietonista i tłumacz z rosyjskiego, nie mający większych związ-

W. Nałkow s ki, Krytyka „Legendy Młodej Polski”. Notatki. „Kuźnica” 1945, nr 1, s. 13.

O modelowaniu historii w dobie stalinizmu piszą D. Malczewska-Paw ele c oraz T. Pawe1 e c w książce Rewolucja w pamięci historycznej. Porównawcze studia nad praktykami manipulacji zbiorowa pamięcia Polaków w czasach stalinowskich (Kraków 2011). Pozycja ta budzi moje liczne zastrzeżenia. Jednym $z$ nich jest perspektywa przyjęta przez autorów. Porównanie materiałów z okresu stalinizmu i czasów międzywojennych wielokrotnie rodzi u czytelnika przekonanie, że polityka historyczna to cecha charakterystyczna wyłącznie reżimów totalitarnych, co z kolei przeczy założeniom teoretycznym publikacji przedstawionym w pierwszej części pracy. 
ków z lewicowymi partiami w przedwojennej Polsce ${ }^{46}$, postanowił podjąc problem domniemanej współpracy młodopolskiego filozofa $z$ carską Ochraną. Autor krótkiego artykułu, poszukując pretekstu do zajęcia się wspomnianym problemem, powoływał się na wznowione Płomienie, choć od razu dodał, że zalegają one półki i nie cieszą się szczególną popularnością (jak było naprawdę, trudno dociec) ${ }^{47}$. Główny postulat artykułu stanowi ostateczne rozwiąanie sprawy Brzozowskiego. W tym celu przytoczone zostały najważniejsze fakty dotyczące postawienia mu zarzutu i samego procesu. Niestety, śmierć autora Legendy Młodej Polski, potem zaś zawierucha wojenna - doprowadzily do zawieszenia wyroku. Fakt ten zaciążył bardzo na biografii Brzozowskiego. Brak werdyktu okazał się bowiem doskonałym powodem do snucia różnych domysłów i formułowania ocen w zależności od panującej koniunktury ideowej. Sam Wyszomirski przychyla się do stanowiska zakładającego niewinność oskarżonego. Powołuje się tu na argument profesora Witolda Klingera, twierdzącego, że osoba, która napisała Legendę Młodej Polski, nie mogła być zarazem współpracownikiem tajnej carskiej policji ${ }^{48}$. Wprawdzie odwołanie się do argumentu natury psychologicznej wiąże się z małą siłą przekonywania, ale Wyszomirski wykorzystuje taki argument w zakończeniu swojego artykułu. Podobnie jak Adamczewski, uznaje, że tylko osoba bioraca pod uwagę kontekst, w jakim żył i tworzył Brzozowski, oraz uwzględniająca jego charakter może dać odpowiedź na pytanie, czy prawdopodobne było w jego przypadku dokonanie aktu zdrady. Po raz kolejny uruchomienie argumentacji psychologicznej pozwala uniknąc jednoznacznej odpowiedzi co do ostatecznej winy bądź niewinności oskarżonego. Jest to gest zawieszenia, próba uchylenia się od udzielenia definitywnej odpowiedzi. Bardziej niż niechęć wobec wydawania kategorycznych ocen i sądów powinien zadziwić czytelnika powód, dla którego zostały wyciągnięte na światło dzienne sprawy sprzed prawie 40 lat, i to takie, w których przypadku próżno było liczyć na pojawienie się nowych dowodów przybliżających wyjaśnienie.

Replikę na tekst Wyszomirskiego nadesłała Alina Świderska - pisarka, tłumaczka i recenzentka, w czasie wojny zaprzysiężona członkini $\mathrm{AK}^{49}$, niemalże rówieśniczka Brzozowskiego. Warto przytoczyć tę wypowiedź w całości:

wznowienie sprawy Brzozowskiego uważam za niepotrzebne i - co najmniej - za nietaktowne. Zostały nam po nim jego książki, które o nim świadczą i świadczyć będą tak długo, jak długo będzie trwała literatura polska - i pozostały niedowiedzione zarzuty, których echo słabnie coraz bardziej i o których mało kto pamięta. „Verba volant, scripta manent”, swięta prawda!... Wywoływanie ich na powrót rzuciłoby ponownie cień na jego pamięć, która już wybielała w świetle wieczności. Tym bardziej dotyczy to grzechów młodości, zupełnie już zapomnianych, ponieważ wymarli już wszyscy, którzy by mogli coś o tym powiedzieć, a które autor artykułu również przypomina znowu. Gdyby sprawa nie była na to za poważna, należałoby zakończyć przysłowiem: „Panie Boże, broń mnie od przyjaciół”, itd. ${ }^{50}$

Czytając tę bogatą w emocje wypowiedź, powinno się rozumieć ją przede wszystkim jako walkę o dobre imię Brzozowskiego. Warto by było jednak przemyśleć,

Zob. Wspótcześni polscy pisarze i badacze literatury, t. 9, s. 333-336.

Zob. J. Wy s z o m ir s k i, Quid iuris? quid Poloniae? „Nowiny Literackie” 1947, nr 33, s. 23.

Zob. ibidem.

Zob. Stownik badaczy literatury polskiej, t. 6 (2003), s. 291-294.

A. Św id er s k a, Verba volant, scripta manent. „Nowiny Literackie” 1947, nr 36, s. 6. 
w jakim stopniu stanowi ona próbę zabrania głosu w dyskusji na temat filozofa, która toczyła się w prasie. Można tylko podejrzewać, że Świderska zdawała sobie sprawę $\mathrm{z}$ tego, że autor Idei zostanie użyty jako pionek w grze o władzę, dlatego uznała za stosowne wyrazić żywione przez siebie przekonanie, a tym samym włączyć się choć w minimalnym stopniu w krajową dyskusję.

W następnym roku na temat Brzozowskiego zabrała głos Wula Buberowa ${ }^{51}$, żona Rafała Bubera - męża zaufania na procesie, mieszkająca w Nowym Jorku. W swoim liście, podpierając się własnym doświadczeniem (była na rozprawach) oraz materiałami i faktami, za wszelką cenę pragnęła udowodnić niewinność przedwcześnie zmarłego filozofa. Ton listu jest rzeczowy i daleki od emocji. Najistotniejsze okazuja się tu powody jego powstania. Zabranie głosu w dyskusji przez osobę powołująca się na swój bezpośredni udział w opisywanym wydarzeniu miało być jednocześnie dowodem moralnym na niewinność Brzozowskiego. Buberowa wykorzystała tutaj nie tylko pozycję naocznego świadka, ale także przywilej mówienia z zewnątrz. Tym sposobem mogła być przez czytelnika odbierana jako wydająca obiektywne sądy, nie zamieszana w grę polityczną, w którą uwikłany został Brzozowski i - pośrednio - osoby mieszkające w Polsce. Mimo pozorów niezależności deklaracja Buberowej stanowi mocne opowiedzenie się po tej stronie sporu, która za żadną cenę nie mogła pozwolić na monopolizację dyskursu przez jednego nadawcę. Zabranie głosu ma również wymiar biograficzny. Buberowa była świadkiem tamtych wydarzeń i za swój moralny obowiązek uznała obronę prawdy o wypadkach sprzed 40 lat.

Ten mocny i autorytatywny sąd nie pozostał jednakże bez odpowiedzi. W numerze 22 „Nowin Literackich” z 1948 roku list do redakcji w sprawie Brzozowskiego wysyła Henryk Jabłoński ${ }^{52}$ - przyszły profesor historii, przed wojna członek PPS, potem członek KRN i ważna postać życia politycznego okresu komunizmu. Jego wypowiedź wniosła ciekawy wątek do dyskusji. Otóż Jabłoński, jak sam pisał, przypadkowo, jeszcze w 1938 roku, natkną się w Archiwum Wojskowym, wśród akt warszawskiego okręgu wojskowego, na specjalnie wydzielony plik opatrzony nazwą „Sprawa B.”, który miał być przeniesiony do tajnej części archiwum ${ }^{53}$. Pojawiła się sugestia, że komuś z przedwojennego rządu zależało na ukryciu prawdy o sprawie Brzozowskiego. Wyrażenie takiej opinii w 1948 roku jednoznacznie wiązało się $z$ opowiedzeniem się za tezą, że Brzozowski był ideologiem sanacji. Równocześnie Jabłoński dodał, że list Buberowej nie mógł rościć sobie pretensji do zamknięcia dyskusji, gdyż nie wniósł do tematu niczego nowego ${ }^{54}$. Przy okazji tej wypowiedzi warto zastanowić się, dlaczego autorowi tak bardzo zależało na próbie ponownego rozpatrzenia problemu na podstawie materiału dowodowego, który, zdaniem Buberowej, był kompletny, oraz jaki był cel wydobycia na światło dzienne informacji o pliku dokumentów, które jeszcze przed wojną uległy utajnieniu, a które - wedle przypuszczeń - mogły mieć niebagatelne znaczenie dla rozwikłania sprawy. Pojawia się tutaj szereg wątpliwości. Dlaczego Jabłoński, wiedząc o istnie-

W. B u b e r ow a, W sprawie Brzozowskiego. Jw., 1948, nr 19, s. 6.

H. J a błoń ski, Jeszcze o Brzozowskim. Jw., nr 22, s. 7.

Zob. ibidem, s. 7.

Ibidem. 
niu tych dokumentów, nie dążył do ich zbadania? Ani słowem nie wspomniał o podjęciu takich starań. Dlaczego jeszcze przed wojna nie poruszył tej kwestii? Dlaczego wreszcie sam nie powrócił do niej po wojnie, a jedynie zostawił pewne tropy dla zainteresowanych (czy wiodły one do celu, to inna rzecz). Zbierając materiały do niniejszej pracy, nie znalazłem żadnych tekstów podnoszących problem ujawnionych przez Jabłońskiego faktów. Na liście do redakcji jego zaciekawienie się tzw. sprawą Brzozowskiego się kończy. W moim mniemaniu informacje tam zawarte, jeżeli nie są zupełnie nieprawdziwe, to są mocno wątpliwe. Zabranie głosu w tej dyskusji nie łączyło się - według mnie - $z$ chęcią rozwiązania zagadki współpracy Brzozowskiego z Ochraną. Cel listu okazał się zarazem polityczny i ideologiczny. Autorowi chodziło nie tyle o odebranie Buberowej prawa do wypowiadania się z pozycji naocznego świadka, ile o legitymizację tej wiedzy. Mogę jedynie snuć przypuszczenia, że intencją Jabłońskiego było też ponowne zasianie wątpliwości wśród czytelników co do niewinności autora Idei. Pytanie o to, czy działanie takie wiązało się z naciskami politycznymi, czy spowodowały je prawdziwe przekonania Jabłońskiego, musi pozostać bez odpowiedzi.

Cała dyskusja wokół sprawy Brzozowskiego pokazuje, jak żywe było zainteresowanie nie tylko głoszonymi przez niego ideami, ale także jego osobą. Wprawdzie dotarłem jedynie do czterech tekstów (nie znalazłem większej liczby głosów w tej dyskusji), dowodzą one wszakże różnorodności postaw i emocji żywionych wobec zagadnienia. Nawet jeżeli poddany analizie materiał jest niepełny, to moge śmiało stwierdzić, że Brzozowski był nie tylko stawką w grze politycznej, ale też stawką $\mathrm{w}$ grze o rozliczenie się autorów owych tekstów $\mathrm{z}$ własną przeszłością czy próbą pełniejszej i spójniejszej narracji o swojej tożsamości. Tym samym podjęcie na nowo tematu współpracy Brzozowskiego z carską Ochraną stanowi próbę opisania pewnej fazy dziejów wedle wersji wydarzeń rozpowszechnianej przez tychże autorów. W taki zaś sposób legitymizują oni własne postawy, emocje, a także tożsamość, która ma wymiar czasowy, czerpie więc pełnymi garściami z wydarzeń przeszłości. Głosy w dyskusji, jaka toczyła się na łamach „Nowin Literackich”, doskonale odzwierciedlają różnorodność przekonań i prób dyskursywizacji historii i własnego doświadczenia. Od wahania Wyszomirskiego, przez święte oburzenie Świderskiej i narrację świadka - Buberowej, po mocno emocjonalny i nieprzychylny ton Jabłońskiego. Jeszcze raz muszę podkreślić, że głosy te, choć zabierane w konkretnej sprawie, były tak naprawdę świadectwem rozdarcia między biografią i emocjami a zaostrzającym się kursem politycznym. Zabranie głosu stanowiło więc nie tyle przejaw własnych przekonań, ile element szerszego sporu o nową rzeczywistość i jej podbudowę ideową.

Przytaczając i analizując teksty ukazujące się na łamach prasy w latach 19451948, chciałem oddać niepewność, niejednoznaczność, a zwłaszcza bogactwo powojennego okresu. Twierdzenie, jakoby miał on wyłącznie charakter przygotowania do procesu stalinizacji wszystkich dziedzin życia w Polsce Ludowej, może wydać się uzasadnione tylko wtedy, gdy pod uwagę bierze się wydarzenia polityczne, do tego ujmowane wyłącznie $z$ perspektywy poczynań działaczy PPR. Jeśli zaś przyjrzymy się tekstom kultury, świadectwom epoki, te trzy lata jawią się jako czas gorączkowego zabiegania o znalezienie dla siebie miejsca w nowym świecie. Chodzi tu nie tylko o sferę materialną i przestrzeń życia codziennego, ale także o świat 
wartości i idei. Osoby pamiętające lata przedwojenne musiały poradzić sobie z dziedzictwem przeszłości, przepuszczając ją przez sito niedawnych wydarzeń historycznych. Skutkowało to wielorakimi decyzjami, rozciągającymi się w spektrum między zamilknięciem w imię wyznawanych wartości a cyniczną współpracą z nową władzą. Niestety, wraz ze zbliżaniem się grudnia 1948 wolna wymiana zdań stawała się coraz bardziej utrudniona, a miejsce prawdziwej dyskusji zajmował stalinowski monolog. Kwestie te nie należą już jednak do wyznaczonego zakresu badawczego, tym samym nie poświęcam im tutaj uwagi ${ }^{55}$.

Abstract

PAWEL RAMS Institute of Literary Research of the Polish Academy of Sciences, Warsaw

BETWEEN HISTORY AND BIOGRAPHY THE FUNCTIONING OF STANISLAW BRZOZOWSKI'S THOUGHT WITHIN THE YEARS 1945-1948

The article is an analysis of texts launched from 1945 to 1948 on Stanisław Brzozowski's heritage in postwar Poland. The author of the paper does not limit his observations only to presenting the emerging voices concerning the matter, but presents them as symptoms of a more widespread phenomenon of social, political and cultural character. The problems raised in the paper are the relationship to Polish tradition of non-communist left wing as well as to the issue of writers' identity redefinition stances and beliefs. The author, resorting to case study, also attempts to prove that the first postwar years were the period of boisterous intellectual exchange and discussion on the shape of new Poland not only in its political and social dimension, but also in a cultural one.

55

Zainteresowanych odsyłam do mojego artykułu Pamięć lewicy. Polska myśl socjalistyczna przełomu XIX i XX wieku kontra stalinowski rozrachunek $\mathrm{z}$ reakcja. Przypadek Pawła Hoffmana (w zb.: Historie afektywne i polityki pamięci. Red. E. Wichrowska, A. Szczepan-Wojnarska, R. Sendyka, R. Nycz. Warszawa 2015). 